\title{
Price negotiating for services: elucidating the ambivalent effects on customers' negotiation aspirations
}

\author{
Sascha Alavi ${ }^{1}$ D . Johannes Habel ${ }^{2} \cdot$ Marco Schwenke $^{3} \cdot$ Christian Schmitz $^{1}$ \\ Received: 1 May 2018 / Accepted: 12 July 2019 / Published online: 8 August 2019 \\ (C) The Author(s) 2019
}

\begin{abstract}
Although customers frequently negotiate the prices of both goods and services, academic research has mostly examined negotiations in goods contexts, neglecting the fact that negotiations for services may be different. This study examines the consequences of customers' price negotiation behavior relating to services as compared to goods. Using five empirical studies with field and experimental data, the authors show that services exert ambivalent effects. First, the heterogeneity intrinsic to services leads customers to aspire to better negotiation outcomes because customers perceive higher risk and regard negotiation as more legitimate, particularly if services are customized. Second, the inseparability of services leads customers to lower their negotiation aspirations because they fear negative consequences, particularly if customers are closely integrated in the service process. Building on these findings, the authors conceptualize and test communication strategies that diminish customers' negotiation aspirations. Study results provide actionable recommendations for managers and salespeople in service industries.
\end{abstract}

Keywords Price negotiations · Personal selling · Goods versus services · Heterogeneity · Inseparability

Price negotiations between customers and salespeople are common, with almost half of U.S. consumers negotiating for a better deal on everyday offerings (Consumer Reports 2013). These negotiations pertain to both goods, such as appliances,

Dhruv Grewal served as Area Editor for this article.

Electronic supplementary material The online version of this article (https://doi.org/10.1007/s11747-019-00676-4) contains supplementary material, which is available to authorized users.

Johannes Habel

johannes.habel@wbs.ac.uk

Sascha Alavi

sascha.alavi@rub.de

Marco Schwenke

marco.schwenke@ue-germany.com

Christian Schmitz

christian.schmitz@rub.de

1 Sales \& Marketing Department, University of Bochum, Universitätsstraße 150, 44780 Bochum, Germany

2 Warwick Business School, The University of Warwick, Scarman Rd, Coventry CV4 7AL, UK

3 Business Department, University of Applied Sciences Europe, Reiterweg 26b, 58636 Iserlohn, Germany furniture, and electronics, and services, such as telecommunication services, bank services, and medical services (Consumer Reports 2013; Sharma and Krishnan 2001). In fact, in customer price negotiations, no product category seems to be off limits (Sundem 2010; White 2012).

Academic literature has generated a large body of knowledge on drivers of customer-salespeople negotiation outcomes and on the effectiveness of various negotiation behaviors (e.g., Sharma and Krishnan 2001; Wieseke et al. 2014). Most prior studies have examined negotiations about goods, such as cars or houses (e.g., Pruitt and Syna 1985; White and Neale 1994), or, in business-to-business contexts, industrial plants, raw materials, or electronic equipment (e.g., Carnevale and Isen 1986; Galinsky and Mussweiler 2001). Only a few studies have examined negotiations about services - that is, "deeds, processes, and performances provided, coproduced, or cocreated by one entity or person for and/or with another entity or person" (Zeithaml et al. 2017, p. 4). The limited studies in this area have considered negotiations about a catering service contract (Kopelman et al. 2006) or, in a business-to-business context, an information technology service contract (Adam and Shirako 2013). Some studies have also examined price negotiations for goods-services bundles (e.g., Thompson and Hastie 1990; Van Kleef et al. 2004).

Surprisingly, to the best of our knowledge, no study has examined whether and how price negotiations differ for services 
and goods. We consider this omission to be striking for two reasons. First, the answer to the question of whether and how negotiations about services and goods vary is not intuitive because different theoretical lenses may predict countervailing effects. On the one hand, owing to the potentially increased heterogeneity in the quality of services (e.g., Zeithaml et al. 1985), customers could negotiate harder because they perceive negotiating as more legitimate and aim to reduce their financial risk (e.g., Murray and Schlacter 1990). This approach could result in lower negotiated prices (e.g., Hüffmeier et al. 2014). On the other hand, customers could negotiate more softly in a service context to avoid alienating the service provider and risking erosion of service quality. As a result, negotiated prices could even be higher (e.g., Hüffmeier et al. 2014). In summary, how negotiations differ for services compared to goods is not easily discerned, rendering the issue intriguing for academic research (e.g., Gabbott and Hogg 1994; Murray and Schlacter 1990).

Second, knowledge of how services and goods negotiations differ is of paramount managerial importance, particularly for managers in the surging service sector. Specifically, building on an in-depth understanding of the mechanisms governing services negotiations, practitioners could use targeted strategies that help them enforce prices for service offerings. This approach could alleviate practitioners' concern that salespeople grant discounts too easily (Joseph 2001) and enable them to reach one of their top performance metrics: avoiding discounting (CSO Insights 2014).

Because the impact of services versus goods on price negotiations is not intuitive and is of high relevance for practice, we comprehensively examine this impact theoretically and empirically. We build our conceptualization by integrating aspiration level theory (Siegel and Fouraker 1960) with the IHIP framework representing intangibility, heterogeneity, inseparability, and perishability (Zeithaml et al. 1985). Specifically, we expect that two customer inferences will result from the heterogeneity inherent in services, as service quality may differ depending on time, customer, and producer (Zeithaml et al. 1985). First, we expect customers to infer negotiation legitimacy, defined as the extent to which customers perceive negotiating as customary (e.g., Jang and Chu 2012; Varman and Costa 2008). Second, we expect customers to infer product risk, defined as the extent to which customers anticipate unpleasant consequences from purchasing an offering (Bauer 1960). These inferences should raise customers' negotiation aspirations, or the extent to which customers aim to achieve discounts in price negotiations with salespeople, and thus reduce negotiated prices. Further, we expect this effect to be particularly evident for highly customized services, or offerings that are individually tailored to customers (Gwinner et al. 2005).

Conversely, because services are produced and consumed simultaneously, resulting in inseparability (Zeithaml et al. 1985), we expect customers to fear that hard negotiation may damage the customer's relationship to the service provider and thereby reduce service quality. More formally, we expect that inseparability evokes perceived negotiation risk, defined as a customer's concern that negotiating may result in lower service quality. This concern may lead customers to develop lower negotiation aspirations, which should increase the negotiated price. We hypothesize this effect to be particularly pronounced for situations of high integration, defined as the extent to which customers and service providers act as co-producers of services. On the basis of these hypotheses, we conceptualize and empirically test four managerial communication strategies - negotiation illegitimacy framing, product security framing, negotiation risk framing, and price transparency framing - which we expect to reduce customers' negotiation aspirations when purchasing services with high heterogeneity and low integration.

To test the hypotheses, we conducted five studies. These comprise four experiments (Studies 1, 2, 3, and 5) and one field survey (Study 4), covering almost 1,300 customers (Web Appendix W1.1 gives an overview). We conducted a presurvey to determine the prevalence of negotiations for services and situated all of our studies in industries in which price negotiations are moderately prevalent or highly prevalent (Web Appendix W1.2).

Our study contributes to academic research in three ways. First, by integrating aspiration level theory with the IHIP framework, our work provides detailed insights into the ambivalent effects of services (compared to goods) in price negotiations. While customers' increase in negotiation aspirations owing to a service's heterogeneity may not be particularly surprising, our finding of a negative effect owing to a service's inseparability is an intriguing addition to prior literature. Second, our work has key implications for future negotiation research, as our study reveals that, contingent on the specific characteristics of services (e.g., level of customization and integration), negotiations for services may differ substantially from negotiations for goods. Third, our study conceptualizes and empirically verifies four novel communication strategies that successfully reduce customers' negotiation aspirations, extending the literature on influence tactics in price negotiations (e.g., Bhatia and Gunia 2018; Malhotra and Bazerman 2008). Importantly, managers and salespeople can use these communication strategies to improve price enforcement. For example, by emphasizing that maintaining a good customer relationship is important, they may prevent customers from developing excessive negotiation aspirations.

\section{Theoretical background}

To conceptualize the effect of services versus goods on price negotiations, we integrate two well established theories: aspiration level theory (Siegel and Fouraker 1960) and the IHIP framework (Zeithaml et al. 1985). We illustrate the integration of these theories in Fig. 1, anchor it in prior literature in Table 1, and elaborate in the following discussion. 


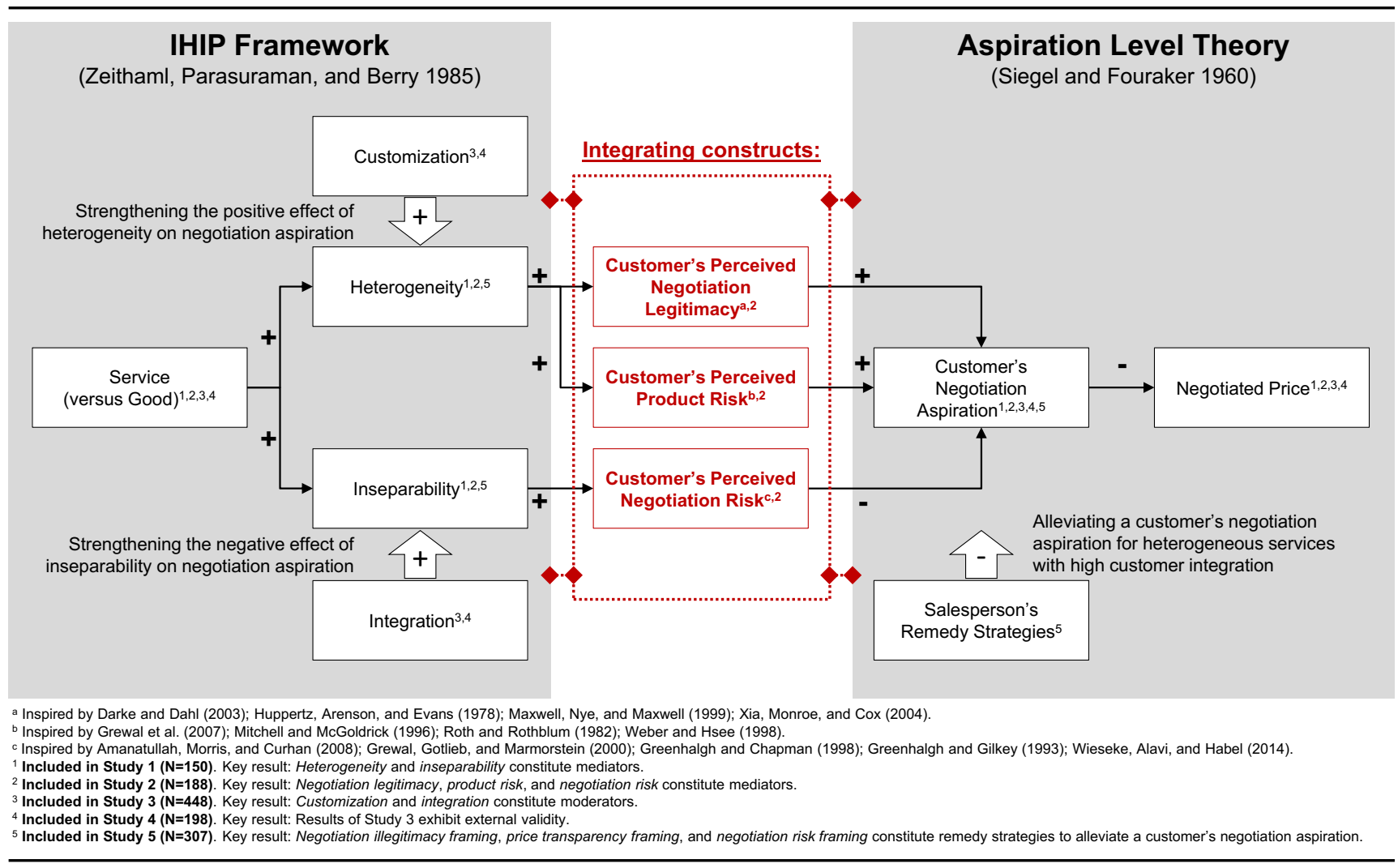

Fig. 1 Conceptual framework integrating the IHIP framework and aspiration level theory

Aspiration level theory (Siegel and Fouraker 1960) proposes that an individual enters a negotiation hoping to achieve a certain goal. This goal is a crucial driver of the individual's negotiation behavior and success (Thompson 1995), as an individual with a high aspiration level is likely to make high demands in a negotiation, which signals unwillingness to yield to the opposing party (Hüffmeier et al. 2014; Siegel and Fouraker 1960). As a result, the other party is more likely to concede, which improves the focal individual's economic outcomes (Hüffmeier et al. 2014). Thus, "it pays to be tough" (MacMurray and Lawler 1986, p. 35).

Prior literature has established that the level of aspiration differs across negotiators, resulting from factors such as personality, needs, and interpersonal perceptions (e.g., Barry and Friedman 1998; Hüffmeier et al. 2014; Jap et al. 2011). Building on the notion that aspirations form contextually, we propose that customers adjust their aspirations when negotiating about services as opposed to goods. We deduce this proposition by integrating aspiration level theory with the IHIP framework (Zeithaml et al. 1985). Offerings ranking high among the IHIP characteristics tend to be classified as services, and offerings ranking low on these are understood as goods (e.g., Edgett and Parkinson 1993; Zeithaml et al. 1985). We expect two of the characteristics to integrate with aspiration level theory to form countervailing effects (see Fig. 1). First, the heterogeneity of services may lead customers to increase their negotiation aspirations because they perceive negotiating to be more legitimate (e.g., Huppertz et al. 1978) and attempt to reduce their elevated product risk perception (e.g., Weber and Hsee 1998). We expect this effect to be particularly pronounced for highly customized services. Second, we argue that services' inseparability leads customers to lower their negotiation aspirations because they perceive negotiating itself as risky (e.g., Amanatullah et al. 2008). We expect this effect to be particularly pronounced if customers are highly integrated in the service delivery.

We empirically test our corresponding hypotheses in five studies. We first derive and empirically verify the mediating effects linking services and customers' negotiation aspirations. We then derive and empirically verify the moderating effects of customization and integration. Finally, we hypothesize which communication strategies service providers might use to lower their customers' negotiation aspirations.

\section{Hypotheses (Part 1): Mediating effects}

\section{The mediating effect of heterogeneity in services negotiations}

Services are heterogeneous in the sense that their quality typically differs depending on time, customer, and producer (e.g., 


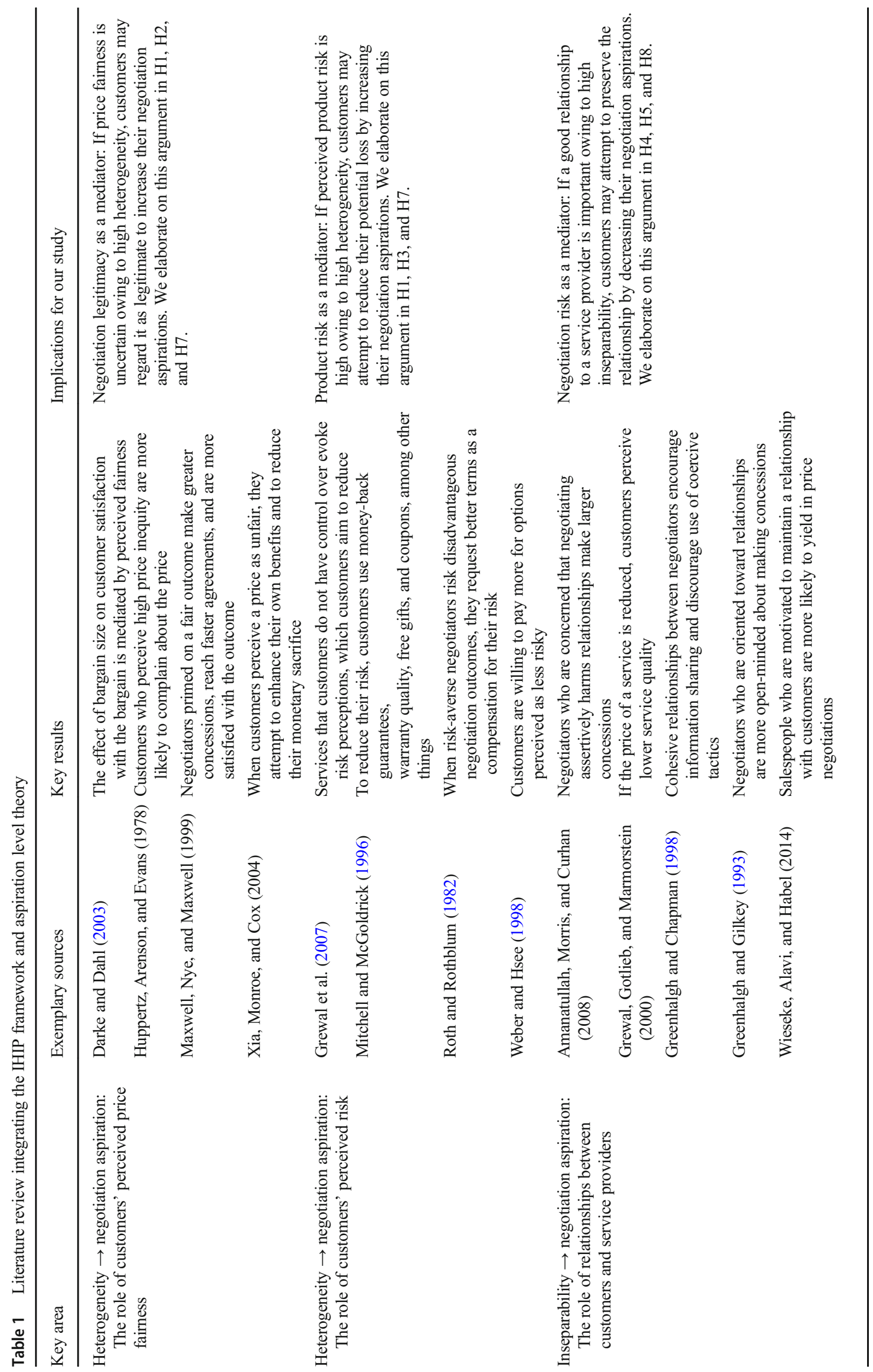


Zeithaml et al. 1985). In contrast, the quality of goods tends to be less contingent on these factors. For example, the quality of a service such as a restaurant meal "can vary from producer to producer, from customer to customer, and from day to day" (Zeithaml et al. 1985, p. 34). Conversely, goods such as canned foods purchased in a grocery store are more likely to exhibit homogeneous quality with negligible variation between different purchases.

As previously noted, heterogeneity increases negotiation aspirations. Customers may perceive negotiating over heterogeneous offerings as more legitimate than negotiating over homogenous offerings, and may attempt to reduce product risk concerning the quality of heterogeneous offerings.

Path via negotiation legitimacy Whether negotiating is perceived as legitimate depends largely on the perceived price fairness of an offering (Xia et al. 2004). Customers perceive a price as fair if their benefits from the offering meet or exceed their purchase costs (Xia et al. 2004; Habel et al. 2016). However, services exhibit greater heterogeneity than goods, rendering a service's quality and benefits to customers uncertain (Edgett and Parkinson 1993). As a result, customers may perceive a service's price fairness as more uncertain as well (Bolton and Alba 2006; Martín-Ruiz and Rondán-Cataluña 2008). In light of such uncertainty, we argue that customers are likely to perceive that an offering's price is subject to debate - that is, to perceive greater negotiation legitimacy (e.g., Xia et al. 2004). As a result, customers may be more likely to raise their negotiation aspirations (Siegel and Fouraker 1960).

Path via product risk The second reason suggesting that the heterogeneity of services increases customers' negotiation aspirations pertains to customers' attempt to reduce their product risk. This proposition draws on perceived risk theory (Bauer 1960; Cox 1967; Cunningham 1967), which holds that customers' perceived risk "is a product of the degree of uncertainty and the extent of consequences that would result from a wrong decision" (Mitchell and McGoldrick 1996, p. 3). Perceived risk is particularly pronounced when purchasing a service as opposed to a good, because a service's heterogeneity renders service quality and thus customers' benefits more uncertain (e.g., Edgett and Parkinson 1993; Murray and Schlacter 1990; Zeithaml et al. 1985).

When facing risky purchase decisions, customers strive to reduce risk (Mitchell and McGoldrick 1996). One way to lower risk is to negotiate down the price and alleviate potential loss in case an offering turns out to exhibit low quality (e.g., Roth and Rothblum 1982). Thus, we argue that to mitigate the increased risk resulting from a service's heterogeneity, customers who purchase services are likely to form elevated negotiation aspirations (e.g., Siegel and Fouraker 1960). Thus:
H1: Negotiations about services (in contrast to goods of comparable performance) increase customers' negotiation aspiration via services' elevated heterogeneity.

H2: The positive effect of heterogeneity on customers' negotiation aspiration is mediated by customers' perceived negotiation legitimacy.

H3: The positive effect of heterogeneity on customers' negotiation aspiration is mediated by customers' perceived product risk.

\section{The mediating effect of inseparability in services negotiations}

Inseparability denotes that services are produced and consumed simultaneously (e.g., Zeithaml et al. 1985). This simultaneity leads to direct provider-consumer contact (e.g., Murray and Schlacter 1990) and "makes it... impossible to test a service before purchase" (Bowen 1990, p. 44). Put differently, service providers initiate service production only after customers and service providers have agreed on a price. In contrast, goods are typically first produced and then purchased and consumed (Zeithaml et al. 1985).

The sequence of negotiation and production poses an interesting challenge to customers in negotiating services pricing: when claiming deep discounts, customers may improve the price they have to pay, but simultaneously risk damaging the relationship with service providers (e.g., Lax and Sebenius 1986). Since the service is still to be produced, customers may fear that such damaged relationships induce service providers to retaliate and expend less effort in the service process, which may lower the service quality (Parasuraman et al. 1988). As a result, we expect customers to reduce their negotiation aspiration for services. We hypothesize:

H4: Negotiations about services (in contrast to goods of comparable performance) decrease customers' negotiation aspiration via services' (see H1) elevated inseparability.

H5: The negative effect of inseparability on customers' negotiation aspiration is mediated by customers' perceived negotiation risk.

Services also differ from goods in terms of intangibility and perishability. Intangibility refers to services as processes that "cannot be seen, felt, tasted, or touched before they are purchased" (Edvardsson, Gustafsson, and Roos 2005, pp. 113114), and perishability states that, unlike goods, services cannot be stored or put into an inventory (e.g., Zeithaml et al. 1985). We do not expect intangibility and perishability to mediate the effect of services on customers' negotiation aspiration because both are less directly related to customers' 
perceptions of service risk and quality as compared to heterogeneity and inseparability. However, we test for such potential mediation effects in our first and second studies.

\section{The effect of negotiation aspiration on negotiated price}

Negotiation aspirations lead to more persistent negotiation behavior, thus improving a customer's negotiation outcome (Hüffmeier et al. 2014; Alavi et al. 2018; Wieseke et al. 2014). To replicate this well accepted finding, we hypothesize:

H6: The higher customers' negotiation aspiration, the lower the negotiated price.

\section{Study 1: Establishing the effects via heterogeneity and inseparability}

\section{Motivation}

The goal of Study 1 was to examine the effects of services versus goods on customers' negotiation aspiration via heterogeneity (H1) and inseparability (H4) as well as the resulting effect on negotiated price (H6). To achieve these goals, we ran an online negotiation simulation.

\section{Procedure}

Testing the differential effects of services and goods on customers' negotiation aspirations requires manipulation of the specific offering customers would negotiate about. A fundamental methodological difficulty is to exclusively manipulate the product type (service versus good) without unintentionally manipulating additional factors, such as the product category or product performance. To cope with these difficulties, we kept constant the object to be negotiated - a car - and manipulated the pricing model of how this car was provided to customers. More specifically, in the goods condition, participants were purchasing a car whereas in two alternative services conditions, participants were either leasing the car or entering a pay-per-use contract (e.g., Bagga et al. 2018). Leasing and pay-per-use are two well established approaches to servitize traditional goods offerings (Tukker 2004; Vargo and Lusch 2004), and over 70\% of customers negotiate the price when purchasing these offerings (Web Appendix 1.2).

To avoid unintentional manipulation of product performance, we kept constant the perceived benefits of the car as well as the total costs and residual value. Specifically, we informed participants that the car fully satisfied their needs and that the total price to them (for either the upfront purchase or all leasing rates combined or all pay-per-use rates combined) amounted to $\$ 18,000$. To verify that residual value is comparable across the services and goods conditions, we informed participants in both conditions that after ten years the car has a value of zero and needs to be replaced. Web Appendix W2.1 provides the detailed treatments.

We used Mechanical Turk to acquire 150 participants (54\% male; mean age, 34.01 years), which were randomly divided into three groups (good: purchase versus service: leasing versus service: pay-per-use) with a between-subjects design. After reading the scenario, participants were asked whether they intended to negotiate. Those who replied affirmatively entered a price negotiation and were asked to provide their initial counter-offer.

Following established procedures in price negotiation research, the computer assumed the salesperson's role in the price negotiations (e.g., Maxwell et al. 1999; Sinaceur et al. 2011; Van Kleef et al. 2004). We used the formula $\left(\mathrm{Z}-(\mathrm{Y}-\mathrm{X})^{*} 0.6\right)$ for the calculation of the computer's counter-offer (Balakrishnan and Eliashberg 1995; Maxwell et al. 1999). For example, in the third round of negotiation $(t=3), Z$ is equal to the computer's offer in $t$ $=2$ (thus, in the first round $\mathrm{Z}$ amounts to 18,000 ), $\mathrm{Y}$ corresponds to the customer's offer in $\mathrm{t}=3$, and $\mathrm{X}$ is equal to the customer's offer in $\mathrm{t}=2$. Put differently, "when the buyer [makes] a price concession the computer [makes] a concession $60 \%$ as large" (Maxwell et al. 1999, p. 554). Since in the first round of negotiation $(t=0) X$ is not available, we defined $X$ with the formula $(\mathrm{Y}-(18,000-\mathrm{Y}) * 0.6)$ for the first round.

One round of negotiation ended after the customer submitted an offer and the computer showed a counter-offer. The participant could then accept the counter-offer, submit a new offer, or abort the negotiation. In turn, the computer accepted the customer's offer when it was higher or equal to the next offer the computer would make. If no agreement was reached by the sixth negotiation round, the computer aborted the negotiation. This approach ensured that participants did not negotiate for an unrealistic amount of time, just to exhaust the algorithm, for example.

\section{Measures}

Negotiation aspiration We operationalized customers' negotiation aspiration as a participant's requested discount in the initial counter-offer (e.g., White and Neale 1994). For participants who did not choose to negotiate, negotiation aspiration was set to 0 .

Negotiated price If a negotiation ended successfully, the customers' negotiated price equaled the agreed-upon price. If a negotiation ended in an impasse, negotiated price attained a missing value. For participants who chose not to negotiate, negotiated price was set to the list price indicated in the scenario.

Service versus good We operationalized the experimental treatment using dummy variables with the goods group coded 
as 0 and the services group coded as 1 . As we use two alternative manipulations of services-leasing and pay-per-use pricing - we specified two dummy variables with the goods group as the baseline condition (Aiken and West 1991).

IHIP dimensions We measured intangibility, heterogeneity, inseparability, and perishability on seven-point scales.

Control variables To account for inter-individual predispositions to ask for discounts when interacting with salespeople, we collected customers' general negotiation propensity (Schneider et al. 1999; Wieseke et al. 2014). In addition, to account for differences in negotiation behavior related to the product category, we controlled for participants' negotiation expectation (Oliver et al. 1994). The Appendix provides information on all survey scales and Web Appendix W2.2 provides detailed statistics on all experimental cells.

\section{Results}

Validity checks We conducted five checks to verify the validity of our manipulations. We verified that (1) our manipulations worked as intended, (2) participants were comparable in all conditions, (3) participants perceived the scenario as realistic, (4) participants did not know the hypotheses of this study, and (5) we did not unintentionally manipulate factors beyond the offering type (such as product value). All checks supported the validity of our experimental design (see Web Appendix W2.3 for details). ${ }^{1}$

Main results To test our hypotheses, we specified a path model in line with Fig. 1. That is, following the recommendation to include experimental treatments in structural equation models (Bagozzi 1977; MacKenzie 2001), we specified the effect of our independent variables (i.e., the two dummies indicating service versus good) on the four IHIP dimensions. We also specified the effects of the IHIP dimensions on negotiation aspiration and the effect of negotiation aspiration on negotiated price. Last, in line with common practice in mediation analysis (Baron and Kenny 1986; Shrout and Bolger 2002), we specified direct effects of the services versus goods dummies on negotiation aspiration and negotiated price.

We estimated the path model using Mplus 7 (Muthén and Muthén 2012). The results are provided in Table 2 (Model 1). First, in line with $\mathrm{H} 1$ and $\mathrm{H} 4$, negotiation aspiration is affected by heterogeneity (positively: $\beta=.17, p<.10$ ) and inseparability (negatively: $\beta=-.20, p<.10$ ). To test our propositions in that heterogeneity and inseparability mediate the effect of services versus goods on negotiation aspiration, we estimated

\footnotetext{
${ }^{1}$ We conducted the same validity checks for our further experiments, Study 2 (see Web Appendix W3.3), Study 3 (see Web Appendix W4.5), and Study 5 (see Web Appendix W6.3).
}

the indirect effects by bootstrapping parameter estimates using bias-corrected confidence intervals (CIs) and 500 repetitions (MacKinnon et al. 2004). Such CIs are especially useful to take potential non-normality of the parameter estimate distribution into account. Results reveal that the indirect effect of the services (leasing) versus goods condition on negotiation aspiration via heterogeneity is significantly positive (unstandardized estimate $\mathrm{b}=1.68, p<.10, \mathrm{CI}=90 \%$ ) and the indirect effect via inseparability is significantly negative $(b=-2.48, p$ $<.05, \mathrm{CI}=95 \%$ ). This result is mirrored in the services (payper-use) versus goods condition regarding the heterogeneity indirect effect $(\mathrm{b}=1.68, p<.05, \mathrm{CI}=95 \%)$ and the inseparability indirect effect $(\mathrm{b}=-2.03, p<.10, \mathrm{CI}=90 \%)$. These results provide first support for $\mathrm{H} 1$ and $\mathrm{H} 4$, suggesting that services exhibit ambivalent effects on a customer's negotiation aspiration. These opposing effects cancel each other out and result in a total null effect of services versus goods on negotiation aspiration $\left(\mathrm{b}_{\text {total leasing }}=-.80, p>.10 ; \mathrm{b}_{\text {total pay }}\right.$ per-use $=-.35, p>.10$ ).

Second, in H6 we argued that a customer's negotiation aspiration lowers the negotiated price. The effect of negotiation aspiration on negotiated price is significantly negative $(\beta$ $=-.82, p<.01$ ), confirming H6. Third, intangibility and perishability do not emerge as mediators of the effect of services versus goods on negotiation aspiration $(p>.10)$.

Robustness checks We verified the robustness of our results in two ways. First, we repeated our analysis without controlling for a customer's general negotiation propensity and negotiation expectation (Model 2 in Table 2). Results remained fully stable. Second, we replicated our estimation of indirect effects using the PROCESS macro (Hayes and Preacher 2014). Again, results fully confirm our main analysis, suggesting that heterogeneity positively mediates the effect of services versus goods on negotiation aspiration (for leasing: $\beta_{\text {indirect }}=2.93, \mathrm{Cl}_{90 \% \text { lower }}=.23$; $\mathrm{CI}_{90 \%}$ upper $=6.58 ; p<.10$; for pay-per-use pricing: $\beta_{\text {indirect }}=$ $3.04, \mathrm{CI}_{95 \% \text { lower }}=.20 ; \mathrm{CI}_{90 \%}$ upper $\left.=6.94 ; p<.05\right)$ and inseparability negatively mediates (for leasing: $\beta_{\text {indirect }}=-3.67, \mathrm{CI}_{95 \%}$ lower $=-7.80 ; \mathrm{CI}_{95 \% \text { upper }}=-.32 ; p<.95$; for use-based pricing: $\beta_{\text {indirect }}=-2.72, \mathrm{CI}_{90 \% \text { lower }}=-6.47 ; \mathrm{CI}_{90 \% \text { upper }}=-.12 ; p<.10$ ).

\section{Study 2: Elucidating customers' inferences from heterogeneity and inseparability}

\section{Motivation}

Study 2 zooms in on the psychological mechanism linking heterogeneity and inseparability and customers' negotiation aspiration. We predict heterogeneity to increase customers' negotiation aspiration through elevated negotiation legitimacy $(\mathrm{H} 2)$ and product risk (H3), whereas we predict inseparability to reduce negotiation aspiration through elevated negotiation risk (H5). 
Table 2 Study 1: Estimated path coefficients

\begin{tabular}{|c|c|c|c|}
\hline Path & Hypotheses & $\begin{array}{l}\text { Model 1: } \\
\text { Full Model }\end{array}$ & $\begin{array}{l}\text { Model 2: } \\
\text { No Controls }\end{array}$ \\
\hline \multicolumn{4}{|l|}{ Effects of services on IHIP dimensions } \\
\hline Good $(0)$ versus service: leasing $(1) \rightarrow$ intangibility & & $.09^{\text {n.s. }}$ & $.11^{\text {n.s. }}$ \\
\hline Good $(0)$ versus service: leasing $(1) \rightarrow$ heterogeneity & & $.16^{\dagger}$ & $.17^{\dagger}$ \\
\hline Good $(0)$ versus service: leasing $(1) \rightarrow$ inseparability & & $.21 *$ & $.21 *$ \\
\hline Good $(0)$ versus service: leasing $(1) \rightarrow$ perishability & & $.21 *$ & $.21 *$ \\
\hline \multicolumn{4}{|l|}{ Effects of services on IHIP dimensions } \\
\hline Good $(0)$ versus service: pay-per-use $(1) \rightarrow$ intangibility & & $.10^{\text {n.s. }}$ & $.11^{\text {n.s. }}$ \\
\hline Good $(0)$ versus service: pay-per-use $(1) \rightarrow$ heterogeneity & & $.16^{\dagger}$ & $.17^{\dagger}$ \\
\hline Good $(0)$ versus service: pay-per-use $(1) \rightarrow$ inseparability & & $.16^{\dagger}$ & $.16^{\dagger}$ \\
\hline Good $(0)$ versus service: pay-per-use $(1) \rightarrow$ perishability & & $.15^{\text {n.s. }}$ & $.15^{\text {n.s. }}$ \\
\hline \multicolumn{4}{|l|}{ Effects of IHIP dimensions on customers' negotiation aspiration } \\
\hline Intangibility $\rightarrow$ negotiation aspiration & & $-.12^{\text {n.s. }}$ & $-.04^{\text {n.s. }}$ \\
\hline Heterogeneity $\rightarrow$ negotiation aspiration & & $.17^{\dagger}$ & $.23 * *$ \\
\hline Inseparability $\rightarrow$ negotiation aspiration & & $-.20^{\dagger}$ & $-.19^{\dagger}$ \\
\hline Perishability $\rightarrow$ negotiation aspiration & & $-.00^{\text {n.s. }}$ & $-.08^{\text {n.s. }}$ \\
\hline \multicolumn{4}{|l|}{ Effects of customers' negotiation aspiration on customers' negotiated price } \\
\hline Negotiation aspiration $\rightarrow$ negotiated price & H6: - & $-.82 * *$ & $-.82 * *$ \\
\hline \multicolumn{4}{|l|}{ Controlled paths } \\
\hline Good (0) versus service: leasing $(1) \rightarrow$ negotiation aspiration & & $.03^{\text {n.s. }}$ & $.04^{\text {n.s. }}$ \\
\hline Good $(0)$ versus service: leasing $(1) \rightarrow$ negotiated price & & $-.00^{\text {n.s. }}$ & $.00^{\text {n.s. }}$ \\
\hline Good $(0)$ versus service: pay-per-use $(1) \rightarrow$ negotiation aspiration & & $.11^{\text {n.s. }}$ & $.10^{\text {n.s. }}$ \\
\hline Good ( 0 ) versus service: pay-per-use $(1) \rightarrow$ negotiated price & & $.04^{\text {n.s. }}$ & $.05^{\text {n.s. }}$ \\
\hline \multicolumn{4}{|l|}{ Effects of control variables } \\
\hline General negotiation propensity $\rightarrow$ negotiation aspiration & & $.16^{\dagger}$ & - \\
\hline Negotiation expectation $\rightarrow$ negotiation aspiration & & $.17^{\dagger}$ & - \\
\hline Negotiation expectation $\rightarrow$ intangibility & & $.23 * *$ & - \\
\hline Negotiation expectation $\rightarrow$ heterogeneity & & $.14^{\dagger}$ & - \\
\hline \multicolumn{4}{|l|}{ Model fit } \\
\hline Comparative fit index (CFI) & & .97 & 1.00 \\
\hline Root mean square error of approximation (RMSEA) & & .10 & .00 \\
\hline Standardized root mean square residual (SRMR) & & .05 & .00 \\
\hline \multicolumn{4}{|l|}{ Bootstrapped Indirect Effects } \\
\hline Good $(0)$ versus service: leasing $(1) \rightarrow$ intangibility $\rightarrow$ negotiation aspiration & & $-.70^{\text {n.s. }}$ & $-.23^{\text {n.s. }}$ \\
\hline Good (0) versus service: leasing $(1) \rightarrow$ heterogeneity $\rightarrow$ negotiation aspiration & H1: + & $1.68^{\dagger}$ & $2.41^{\dagger}$ \\
\hline Good $(0)$ versus service: leasing $(1) \rightarrow$ inseparability $\rightarrow$ negotiation aspiration & H4: - & $-2.48^{\dagger \dagger}$ & $-2.34^{+\dagger}$ \\
\hline Good $(0)$ versus service: leasing $(1) \rightarrow$ perishability $\rightarrow$ negotiation aspiration & & $-.08^{\text {n.s. }}$ & $-.96^{\text {n.s. }}$ \\
\hline Good $(0)$ versus service: pay-per-use $(1) \rightarrow$ intangibility $\rightarrow$ negotiation aspiration & & $-.75^{\text {n.s. }}$ & $-.25^{\text {n.s. }}$ \\
\hline Good $(0)$ versus service: pay-per-use $(1) \rightarrow$ heterogeneity $\rightarrow$ negotiation aspiration & & $1.68^{\dagger \dagger}$ & $2.43^{\dagger+}$ \\
\hline Good (0) versus service: pay-per-use $(1) \rightarrow$ inseparability $\rightarrow$ negotiation aspiration & & $-2.03^{\dagger}$ & $-1.92^{\dagger}$ \\
\hline Good $(0)$ versus service: pay-per-use $(1) \rightarrow$ perishability $\rightarrow$ negotiation aspiration & & $-.06^{\text {n.s. }}$ & $-.71^{\text {n.s. }}$ \\
\hline
\end{tabular}

n.s. $p>.10,^{\dagger} p<.10, * p<.05, * * p<.01$ (two-tailed); standardized coefficients. For the indirect effects unstandardized coefficients are reported and ${ }^{\dagger \dagger}=$ $95 \%$ confidence interval (CI) ${ }^{\dagger}=90 \%$ (CI). We dropped controlled effects of negotiation expectation on negotiated price, inseparability, and perishability because they emerged as insignificant. For the same reason, we dropped the controlled effect of general negotiation propensity on negotiated price.

\section{Procedure}

We adopted an approach similar to that in Study 1. To manipulate the offering type, in the goods condition we told participants that they were purchasing a lawn mower, while in the services condition we told participants they were interested in purchasing a lawn mowing service contract. Customers often negotiate for both lawn mowers (27.9\%) and mowing services (43.5\%), rendering these offerings an adequate context for this study (Web Appendix W1.2).

As in the previous study, to avoid unintentional manipulation of product performance we kept constant the perceived benefits of the offerings and the total costs and residual value. We informed participants that the offer fully satisfied their needs and that they paid the total price upfront. To verify that residual value is comparable across the services and goods conditions, we informed participants in both conditions that after five years the offer has a value of zero and needs to be replaced or expires (Web Appendix W3.1).

We used Mechanical Turk to acquire 188 participants for the study (65.5\% male; mean age, 32.6 years). The participants were randomly divided into two groups (service versus good) with a between-subjects design. Participants first read the scenario and then indicated whether they intended to negotiate about the offer, with those who confirmed providing their initial counter-offer. The negotiation simulation followed the same procedures as in Study 1.

\section{Measures}

We devised measures for this study closely in line with the previous study (negotiation aspiration, negotiated price, IHIP, the experimental service versus good treatment dummy with good coded as 0 and service coded as 1 , as well as control 
variables). For the new constructs in this study-customers' product and negotiation risk perceptions and negotiation legitimacy —we adopted measures from prior research and adjusted them if necessary. The Appendix provides information on all survey scales and Web Appendix W3.2 provides detailed statistics on all experimental cells. Web Appendix W3.3 provides validity checks.

\section{Results}

To test our hypotheses, we specified a path model in line with Fig. 1. That is, following the recommendation to include experimental treatments in structural equation models (Bagozzi 1977; MacKenzie 2001), we specified the effect of our independent variables (i.e., the dummy indicating service versus good) on the IHIP dimensions. We also specified the effects of the IHIP dimensions on negotiation aspiration and the effect of negotiation aspiration on negotiated price. Importantly, we included customers' perceived product risk, negotiation risk, and negotiation legitimacy as mediators of the heterogeneity/ inseparability-negotiation aspiration linkage in the model. Last, in line with common practice (Shrout and Bolger 2002), we specified direct effects of the service versus good dummies on negotiation aspiration and negotiated price. Using Mplus 7 (Muthén and Muthén 2012), we estimated one model replicating Study 1 (Table 3, Model 1), and then a model adding our focal mediators (Model 2). The model exhibits a good fit $(\mathrm{CFI}=.95$, SRMR $=.04$; RMSEA $=.12)$. Results are provided in Table 3.

We can replicate results of Study 1 for $\mathrm{H} 1$ and $\mathrm{H} 4$ because services significantly increase heterogeneity and inseparability, and negotiation aspiration is positively affected by heterogeneity $(\beta=.20, p<.01)$ and negatively by inseparability $(\beta=$ $-.16, p<.05$; see Model 1).

Table 3 Study 2: Estimated path coefficients

\begin{tabular}{|c|c|c|c|}
\hline Path & Hypotheses & $\begin{array}{l}\text { Model 1: } \\
\text { Replication of Study } 1\end{array}$ & $\begin{array}{l}\text { Model 2: } \\
\text { Full Model Study } 2\end{array}$ \\
\hline \multicolumn{4}{|l|}{ Effects of services on IHIP dimensions } \\
\hline Good $(0)$ versus service $(1) \rightarrow$ intangibility & & $.38 * *$ & $.38 * *$ \\
\hline Good (0) versus service $(1) \rightarrow$ heterogeneity & & $.16^{*}$ & $.16^{*}$ \\
\hline Good $(0)$ versus service $(1) \rightarrow$ inseparability & & $.17 *$ & $.17^{*}$ \\
\hline Good $(0)$ versus service $(1) \rightarrow$ perishability & & $.28 * *$ & $.28 * *$ \\
\hline \multicolumn{4}{|l|}{ Effects of IHIP on customers' inferences } \\
\hline Heterogeneity $\rightarrow$ negotiation legitimacy & & - & $.28 * *$ \\
\hline Inseparability $\rightarrow$ negotiation legitimacy & & - & $.13^{\text {n.s. }}$ \\
\hline Heterogeneity $\rightarrow$ product risk & & - & $.23 *$ \\
\hline Inseparability $\rightarrow$ product risk & & - & $.08^{\text {n.s. }}$ \\
\hline Inseparability $\rightarrow$ negotiation risk & & - & $.19 *$ \\
\hline Heterogeneity $\rightarrow$ negotiation risk & & - & $.26 * *$ \\
\hline \multicolumn{4}{|l|}{ Effects of customers' inferences on negotiation aspiration } \\
\hline Negotiation legitimacy $\rightarrow$ negotiation aspiration & & - & $.33 * *$ \\
\hline Product risk $\rightarrow$ negotiation aspiration & & - & $.15^{*}$ \\
\hline Negotiation risk $\rightarrow$ negotiation aspiration & & - & $-.14 *$ \\
\hline \multicolumn{4}{|l|}{ Effects of negotiation aspiration on negotiated price } \\
\hline Negotiation aspiration $\rightarrow$ negotiated price & H6: - & $-.86^{* *}$ & $-.84 * *$ \\
\hline \multicolumn{4}{|l|}{ Controlled paths } \\
\hline Good $(0)$ versus service $(1) \rightarrow$ negotiation aspiration & & $.12^{\text {n.s. }}$ & $.10^{\text {n.s. }}$ \\
\hline Good $(0)$ versus service $(1) \rightarrow$ negotiated price & & $.04^{\text {n.s. }}$ & $.04^{\text {n.s. }}$ \\
\hline Intangibility $\rightarrow$ negotiation aspiration & & $-.13^{\text {n.s. }}$ & $-.03^{\text {n.s. }}$ \\
\hline Intangibility $\rightarrow$ negotiated price & & $.02^{\text {n.s. }}$ & $-.00^{\text {n.s. }}$ \\
\hline Heterogeneity $\rightarrow$ negotiation aspiration & & $.20 *$ & $.08^{\text {n.s. }}$ \\
\hline Heterogeneity $\rightarrow$ negotiated price & & $.02^{\text {n.s. }}$ & $.02^{\text {n.s }}$ \\
\hline Inseparability $\rightarrow$ negotiation aspiration & & $-.16^{*}$ & $-.22 * *$ \\
\hline Inseparability $\rightarrow$ negotiated price & & $.03^{\text {n.s. }}$ & $.04^{\text {n.s. }}$ \\
\hline Perishability $\rightarrow$ negotiation aspiration & & $.08^{\text {n.s. }}$ & $.08^{\text {n.s. }}$ \\
\hline Perishability $\rightarrow$ negotiated price & & $-.00^{\text {n.s. }}$ & $-.01^{\text {n.s. }}$ \\
\hline Negotiation legitimacy $\rightarrow$ negotiated price & & - & $-.06^{\text {n.s. }}$ \\
\hline Product risk $\rightarrow$ negotiated price & & - & $.04^{\text {n.s. }}$ \\
\hline Negotiation risk $\rightarrow$ negotiated price & & - & $.04^{\text {n.s. }}$ \\
\hline \multicolumn{4}{|l|}{ Model fit } \\
\hline Comparative fit index (CFI) & & 1.00 & .95 \\
\hline Root mean square error of approximation (RMSEA) & & .00 & .12 \\
\hline Standardized root mean square residual (SRMR) & & .00 & .04 \\
\hline \multicolumn{4}{|l|}{ Bootstrapped indirect effects } \\
\hline Good $(0)$ versus service $(1) \rightarrow$ heterogeneity $\rightarrow$ negotiation legitimacy $\rightarrow$ negotiation aspiration & $\mathrm{H} 2:+$ & - & $5.52^{\dagger \dagger}$ \\
\hline Good $(0)$ versus service $(1) \rightarrow$ heterogeneity $\rightarrow$ product risk $\rightarrow$ negotiation aspiration & $\mathrm{H} 3:+$ & - & $2.11^{\dagger \dagger}$ \\
\hline Good $(0)$ versus service $(1) \rightarrow$ inseparability $\rightarrow$ negotiation risk $\rightarrow$ negotiation aspiration & H5:- & - & $-1.59^{\dagger \dagger}$ \\
\hline
\end{tabular}

n.s. $p>.10,{ }^{\dagger} p<.10, * p<.05, * * p<.01$ (two-tailed); standardized coefficients. For the indirect effects unstandardized coefficients are reported and ${ }^{\dagger \dagger}=$ $95 \%$ confidence interval (CI), ${ }^{\dagger}=90 \%$ (CI). We dropped controlled effects of negotiation expectation and general negotiation propensity on negotiation aspiration and negotiated price because they emerged as insignificant. 
To test our propositions in $\mathrm{H} 2, \mathrm{H} 3$ and $\mathrm{H} 5$ that negotiation legitimacy, product risk, and negotiation risk mediate the effect of services versus goods on negotiation aspiration, we included the respective mediators in the model (Fig. 1). To test the mediation hypotheses, we estimated the specified model including the mediators and control variables and then calculated indirect effects by bootstrapping parameter estimates and using bias-corrected confidence intervals and 500 repetitions (MacKinnon et al. 2004). Table 3, Model 2 gives the individual path coefficients. Results reveal that the indirect effect of services versus goods on negotiation aspiration via heterogeneity and product risk is significantly positive (unstandardized estimate $\mathrm{b}=2.11, p<.05, \mathrm{CI}=95 \%$ ) and the indirect effect via heterogeneity and negotiation legitimacy is significantly positive $(b=5.52, p<.05, \mathrm{CI}=95 \%)$. In contrast, the indirect effect of services versus goods on negotiation aspiration via inseparability and negotiation risk is significantly negative $(b=-1.59, p<.05, \mathrm{CI}=95 \%)$. The direct effect of service versus good on negotiation aspiration is insignificant $(\mathrm{b}=35.64, p>.10)$. This finding provides support for $\mathrm{H} 2, \mathrm{H} 3$, and $\mathrm{H} 5$, suggesting that services exhibit ambivalent effects on a customer's negotiation aspiration through negotiation legitimacy, product risk, and negotiation risk. In confirmation of $\mathrm{H6}$, the effect of negotiation aspiration on negotiated price is significantly negative $(\beta=-.85, p<.01)$. Intangibility and perishability do not emerge as mediators of the effect of services versus goods on negotiation aspiration ( $p$ $>.10)$.

Robustness checks We verified the robustness of our results in two ways. First, we repeated our analysis without controlling for a customer's general negotiation propensity and negotiation expectation (Model 2 in Table 3). Results remained fully stable. Second, we replicated our estimation of indirect effects using the PROCESS macro (Hayes and Preacher 2014). Again, results confirm our main analysis, suggesting that heterogeneity positively mediates the effect of services versus goods on negotiation aspiration via negotiation legitimacy $\left(\beta_{\text {indirect }}=6.08, \mathrm{CI}_{95 \text { lower }}=.65, \mathrm{CI}_{95}\right.$ upper $\left.=15.06, p<.05\right)$ as well as product risk $\left(\beta_{\text {indirect }}=2.44, \mathrm{CI}_{90 \text { lower }}=.09, \mathrm{CI}_{90}\right.$ upper $=6.37, p<.10)$ and inseparability negatively mediates via negotiation risk $\left(\beta_{\text {indirect }}=-1.65, \mathrm{CI}_{90}\right.$ lower $=-4.40, \mathrm{CI}_{90}$ upper $=-.01, p<.10)$.

\section{Hypotheses (Part 2): Moderating effects}

\section{The moderating effect of customization in services negotiations}

To provide further evidence of the theoretical mechanisms proposed in $\mathrm{H} 1-\mathrm{H} 5$, we propose two moderators (customization and integration) that should strengthen the hypothesized effects of services compared to goods in price negotiations. We first argue that customization elevates negotiation aspirations for services compared to goods. Customization - the individual tailoring of offerings to customers (Gwinner et al. 2005) - increases uncertainty as to whether the offering can succeed. For instance, providers may fail to understand customers' specific needs, to convert these needs into customized specifications, or to produce the offering according to these specifications (Gwinner et al. 2005; Parasuraman et al. 1988). Thus, customers should expect that a customized service offering's quality depends on time, the customer, or the producers' skills - that is, customers may perceive higher heterogeneity (e.g., Zeithaml et al. 1985). Particularly for services, heterogeneity may increase negotiation aspirations as customers perceive negotiating as more legitimate and seek to reduce their product risk (e.g., Xia et al. 2004; Weber and Hsee 1998). Thus, customized service offerings should evoke higher negotiation aspirations.

Notably, these effects should be particularly pronounced for services compared to goods. Quality control is more difficult for services (Zeithaml et al. 1985), which should increase the uncertainty as to whether customization efforts succeed. Quality control is easier for goods because goods have more observable attributes. In summary, we hypothesize:

H7: Customization has a more positive effect on customers' negotiation aspiration for services as compared to goods.

\section{The moderating effect of integration in services negotiations}

Services differ in the extent to which customers are integrated in the service process. For example, while a fast-food restaurant requires little customer input, marriage counseling requires customers' co-creation of the outcome together with the service providers (Bitner et al. 1997).

For two reasons, we expect that the more customers are integrated into the service process the less likely they are to increase their negotiation aspirations. The first reason builds on our derivation of $\mathrm{H} 4$ and $\mathrm{H} 5$. We argued that a service's inseparability of production and consumption leads customers to develop lower negotiation aspirations so as to not threaten the service process and quality. We propose that customers are particularly likely to fear a decline of service quality if they are heavily integrated in the service process, because the more customers are integrated, the more service quality depends on the collaboration of customers and service providers. Collaboration crucially depends on the quality of the relationship between customers and service providers (Payne et al. 2008). Thus, if hard negotiations damage the relationship (e.g., Lax and Sebenius 1986), service quality may be particularly at risk.

Second, customers who are integrated in a service may view price negotiations as particularly inappropriate because they are 
co-producers of the service. In general, when customers enter negotiations with a salesperson, they give reasons for their discount claims and actively question whether the offering is worth its price. However, when customers are heavily integrated in the service and act as co-producers, argumentation and questioning may seem inappropriate. That is, customers who are coproducers of the service may feel as if, by negotiating, they are questioning their own performance or abilities. Because service customers actively strive to maintain a positive self-image (Habel et al. 2017), we expect that highly integrated customers will be more likely to refrain from price negotiations:

H8: Integration reduces customers' negotiation aspiration to a greater extent for services than for goods.

\section{Study 3: Establishing moderating effects of customization and integration}

\section{Motivation}

In Study 3, we aim to fortify the essential role of heterogeneity and inseparability by testing the moderating effects of customization (H7) and integration (H8) in the service versus good-negotiation aspiration relationship. Specifically, customization should increase the heterogeneity of services and enhance the positive effect of good (coded as zero) versus service (coded as 1) on negotiation aspiration. Likewise, integration of customers in the service process should catalyze the effect of a service's inseparability and enhance the negative effect of service versus good on negotiation aspiration.

\section{Procedure}

Study 3 comprises two separate $2 \times 2$ between-subjects negotiation simulations (Study 3a and Study 3b). In both simulations, the first treatment factor pertained to the offering type, service versus good. The second treatment factor manipulated customization to be low or high (in Study 3a) and integration to be low or high (Study 3b). Using Mechanical Turk, we randomly allocated 212 participants $(63.3 \%$ male; mean age, 35.5 years) to Study 3a and 236 participants (58.5\% male; mean age, 33.1 years) to Study $3 b$.

As in the previous studies, we first asked participants to picture themselves in a purchasing situation and then enter a price negotiation. To manipulate the experimental factors rigorously and test our hypotheses in different contexts, we used different scenarios for the two sub-studies. In Study 3a, we simulated the purchase of a house. Participants considered buying either a turnkey house or a construction company's service of building a house. For both offerings, over $80 \%$ of actual customers engage in negotiations (Web Appendix 1.2), rendering this context adequate for our study. To keep the performance and value of the offerings constant, the two conditions indicated the same price and informed participants that the house would fully satisfy their needs. To manipulate customization, we told participants that the house would be highly standardized (low customization) or highly customized (high customization).

In Study 3b, we simulated the purchase of a real estate security offering. Participants considered purchasing either an alarm system (good) or a security service contract (service) for their property at a price of $\$ 2,000$. We again constrained the performance of the offering to be constant across the two product types: a properly secured property for five years, after which the alarm system would have to be replaced or the security service would expire. To manipulate integration, we informed participants that the security system would either run in the background without needing their involvement (low integration) or require close coordination with their dedicated involvement (high integration) (see Web Appendices W4.1 and W4.2). After reading the scenario, participants were asked whether they intended to negotiate about the offer. Those who confirmed entered a price negotiation and provided their initial counter-offer. For the price negotiation process, we used the same algorithm as in Studies 1 and 2. Afterwards, participants answered a set of survey questions.

\section{Measures}

We measured negotiation aspiration as participants' initial discount claim and negotiated price as the ultimate agreedupon price. Dummy variables indicating the treatment conditions served as independent variables (i.e., service (1) versus good (0), high (1) versus low (0) customization, and high (1) versus low (0) integration). In addition, we surveyed participants' general negotiation propensity and negotiation expectation as control variables. The Appendix provides information on all survey scales and Web Appendices W4.3 and W4.4 provide detailed statistics on all experimental cells. Web Appendix W4.5 provides a set of validity checks.

\section{Results}

Study $3 \mathrm{a}$ tests $\mathrm{H} 7$, which predicts that customization positively moderates the effect of service versus good on negotiation aspiration. To test this hypothesis, we conducted an ANOVA and inspected the mean values across the treatment conditions (Fig. 2). A two-way ANOVA with customers' general negotiation propensity and negotiation expectation as covariates revealed a significant main effect of the services versus goods treatment $(\mathrm{F}(1,206)=7.10, p<.01)$, an insignificant main effect of customization $(\mathrm{F}(1,206)=.11, p>.10)$ and, as hypothesized in $\mathrm{H} 7$, a significant interaction effect of the treatment dummies on negotiation aspiration $(\mathrm{F}(1,206)=4.96, p<.05)$. Thus, $\mathrm{H} 7$ receives support. To verify that the pattern of the interaction effect is as hypothesized, we inspected post hoc contrasts. As 
expected, for services, customers' negotiation aspirations are higher for high customization, though only marginally $\left(\mathrm{M}_{\text {negotiation aspiration, low customization }}=12,524, \mathrm{M}_{\text {negotiation aspiration, }}\right.$ high customization $=21,452 ; \Delta \mathrm{M}=8,928 ; \mathrm{F}(1,206)=1.84, p<$ .18). For goods, customers' negotiation aspirations are lower for high customization, though again only marginally $\left(\mathrm{M}_{\text {negotiation }}\right.$ aspiration, low customization $=35,635$ versus $\mathrm{M}_{\text {negotiation aspiration, high }}$ customization $=23,617 ; \Delta \mathrm{M}=-12,018 ; \mathrm{F}(1,206)=3.20, p<.10)$. However, as indicated by the significant two-way interaction effect $(\mathrm{F}(1,206)=4.96, p<.05)$ and as hypothesized, customization increases negotiation aspirations for services to a significantly greater extent than for goods.

Study $3 \mathrm{~b}$ tests $\mathrm{H} 8$, which predicts that integration negatively moderates the effect of service versus good on negotiation aspiration. A two-way ANOVA with customers' general negotiation propensity and negotiation expectation as covariates revealed an insignificant main effect of the services versus goods treatment $(\mathrm{F}(1,230)=2.75, p>.05)$, a significant main effect of the integration treatment $(\mathrm{F}(1,230)=5.84, p<.05)$, and importantly, a significant interaction effect of the treatment dummies on negotiation aspiration $(\mathrm{F}(1,230)=4.19, p<.05)$ (Fig. 2). This finding supports H8. Post hoc contrasts of this interaction effect reveal that for services, integration significantly reduces negotiation aspiration $\left(\mathrm{M}_{\text {negotiation aspiration, low integration }}=810\right.$ versus $\mathrm{M}_{\text {negotiation aspiration, high integration }}=483 ; \Delta \mathrm{M}=-327 ; \mathrm{F}(1,230)=$ $10.15, p<.01)$ while for goods integration does not affect customers' negotiation aspirations $\left(\mathrm{M}_{\text {negotiation aspiration, low integration }}\right.$
$=538$ versus $\mathrm{M}_{\text {aspiration, high integration }}=511 ; \Delta \mathrm{M}=-27 ; \mathrm{F}(1,230)$ $=.07, p>.70$ ). In both sub-studies, negotiation aspiration is negatively correlated with negotiated price $\left(\mathrm{r}_{\text {Study } 3 \mathrm{a}}=-.84, p<\right.$ $\left..01 ; \mathrm{r}_{\text {Study } 3 \mathrm{~b}}=-.85, p<.01\right)$, supporting $\mathrm{H} 6$.

\section{Study 4: Establishing external validity in the field and B2B context}

\section{Motivation}

In Study 4, we aim to establish the external validity of our previous findings. First, we test our propositions using crossindustry field data. Second, as prior studies pertained to a business-to-consumer context, we test the external validity of our findings in a business-to-business context. To this end, we conducted a field survey using a cross-industry sample of professional buyers.

\section{Procedure}

To collect field data, we developed an online questionnaire targeting professional buyers from various industries. The questionnaire asked respondents to relate their survey answers to a supplier that their own company was doing business with on a regular basis and that they were able to evaluate. We asked the professional buyers to indicate an offering they were purchasing
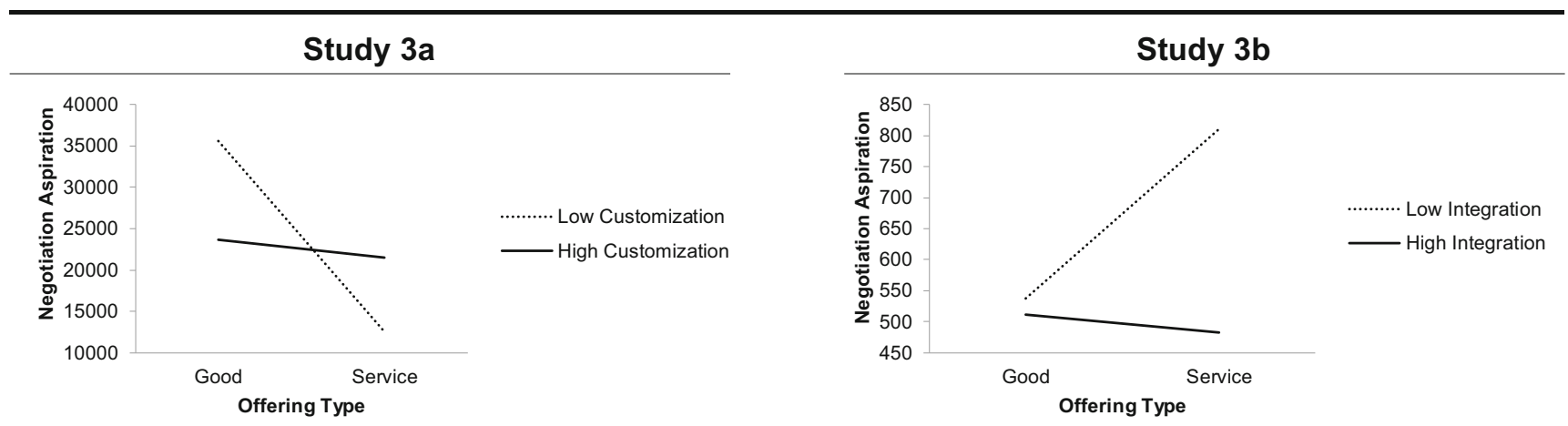

\section{Study 4}
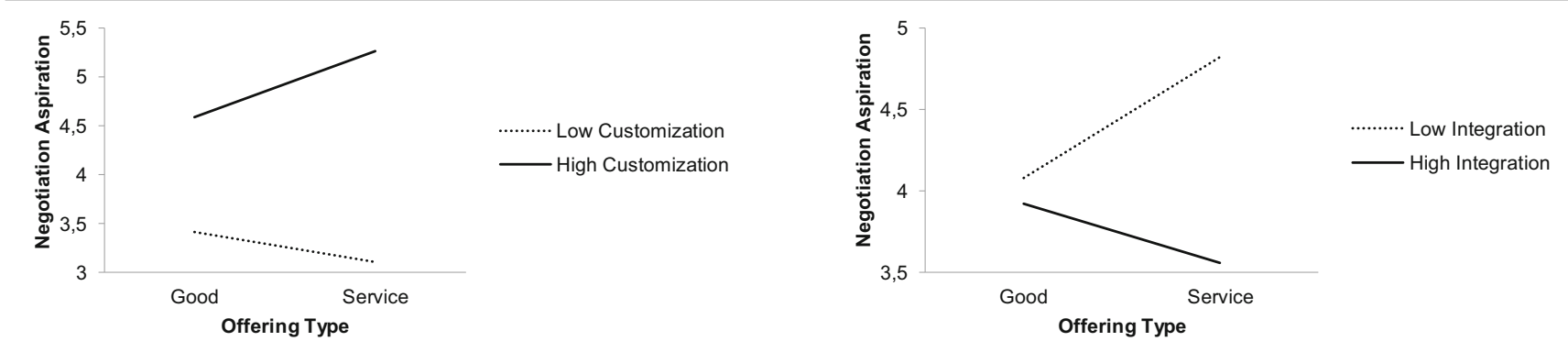

Fig. 2 Studies 3 and 4: Interaction plots 
from the supplier, assess the product type of the offering (service versus good), and evaluate the degree of customization and integration. In addition, respondents appraised their negotiation aspiration as well as the price they generally realize for this offering. Last, we collected a set of control variables. To collect data, we purchased access to 200 professional buyers in the United States through the online panel provider Survey Sampling International (SSI) (62.1\% male; mean age, 45.20 years; see Web Appendix W5.1). As is common with such panel data collections, a response rate is not available.

\section{Measures}

Negotiation aspiration As our sample spans various industries and products, we operationalized respondents' negotiation aspiration through three seven-point Likert items ("In price negotiations about this offering, we are very ...hard / ...tough / ...persistent").

Negotiated price We asked participants what percentage discount they typically realize on the list price of the offering under consideration. We then subtracted this value from $100 \%$ to obtain a measure of negotiated price. Thus, in this study we operationalized negotiated price relative to the list price of an offering.

Service versus good We asked respondents what type of offering they typically purchase from their supplier. We then specified a service (1) versus good (0) dummy, similar to our approach in our previous studies.

Customization and integration We measured customization and integration of the focal offerings that the buyers purchased on survey scales. A sample item of customization is "This offering is individually developed for us" and a sample item of integration is "Our business relationship with this firm is characterized by close cooperation between the two companies."

Control variables Given the cross-industry nature of our data, we controlled for a number of potentially intervening factors: competitive intensity, price performance, product satisfaction, relationship length, company revenue, number of employees in company, and professional experience. The Appendix provides all scales in detail. Web Appendix W5.1 provides descriptive statistics and correlations.

\section{Results}

Main results We specified a path model that included the effect of the service versus good dummy on negotiation aspiration and the effect of negotiation aspiration on negotiated price. As in Study 3, we specified two interaction terms between the service versus good dummy and customization as well as integration. We included the effects of these interaction terms as well as the main effects of customization and integration on negotiation aspiration in our model specification. Last, we included the effects of all control variables on both negotiation aspiration and negotiated price. We estimated the path model using Mplus 7 (Muthén and Muthén 2012). Owing to missing values on all relevant variables, we dropped two observations, leaving a final sample of 198. Results appear in Table 4 (Model 1) and are described below. The model exhibits a good fit to the data $\left(\chi^{2} / \mathrm{df}=2.14 ; \mathrm{CFI}=.90 ; \mathrm{RMSEA}=.07 ; \mathrm{SRMR}=.03\right)$.

Results reveal that the main effect of service versus good on negotiation aspiration is insignificant $(p>.10)$. However, its interactive effect with customization on negotiation aspiration is

Table 4 Study 4: Estimated path coefficients

\begin{tabular}{|c|c|c|c|}
\hline Path & Hypotheses & $\begin{array}{l}\text { Model 1: } \\
\text { Full Model }\end{array}$ & $\begin{array}{l}\text { Model 2: } \\
\text { No Controls }\end{array}$ \\
\hline \multicolumn{4}{|l|}{ Main effects } \\
\hline Good $(0)$ versus service $(1) \rightarrow$ negotiation aspiration & & $.02^{\text {n.s. }}$ & $.06^{\text {n.s. }}$ \\
\hline Negotiation aspiration $\rightarrow$ negotiated price & H6: - & $-.15^{*}$ & $-.20 * *$ \\
\hline Good $(0)$ versus service $(1) \rightarrow$ negotiated price & & $.03^{\text {n.s. }}$ & $.01^{\text {n.s. }}$ \\
\hline \multicolumn{4}{|l|}{ Main effects of moderators } \\
\hline Customization $\rightarrow$ negotiation aspiration & & $.40 * *$ & $.44 * *$ \\
\hline Integration $\rightarrow$ negotiation aspiration & & $-.15^{\text {n.s. }}$ & $-.06^{\text {n.s. }}$ \\
\hline \multicolumn{4}{|l|}{ Interaction effects } \\
\hline Good $(0)$ versus service $(1) \times$ customization $\rightarrow$ negotiation aspiration & $\mathrm{H} 7:+$ & $.17 *$ & $.18^{*}$ \\
\hline Good $(0)$ versus service $(1) \times$ integration $\rightarrow$ negotiation aspiration & H8: - & $-.20 *$ & $-.21 *$ \\
\hline \multicolumn{4}{|l|}{ Controlled effects } \\
\hline Competitive intensity $\rightarrow$ negotiation aspiration & & $.21 * *$ & - \\
\hline Company revenue $\rightarrow$ negotiation aspiration & & $20 * *$ & - \\
\hline Company employees $\rightarrow$ negotiated price & & $-.14^{\dagger}$ & - \\
\hline Professional experience $\rightarrow$ negotiated price & & $.19 * *$ & - \\
\hline \multicolumn{4}{|l|}{ Model fit } \\
\hline $\mathrm{R}^{2}$ of negotiation aspiration & & $.29 * *$ & $.22 * *$ \\
\hline
\end{tabular}

n.s. $p>.10,^{\dagger} p<.10, * p<.05, * * p<.01$ (two-tailed); standardized coefficients. We dropped controlled effects of relationship length, product satisfaction, price performance, company employees, and professional experience on negotiation aspiration, because they emerged as insignificant. For the same reason, we dropped controlled effects of relationship length, product satisfaction, price performance, competitive intensity, and company revenue on negotiated price. 
significantly positive $(\beta=.17, p<.05)$ (Fig. 2$)$. As expected, customization has a more positive effect on negotiation aspiration for services $(\beta=.76, p<.01)$ as compared to goods $(\beta=.40, p<$ .01 ), supporting H7. In addition, the interactive effect of service versus good and integration on negotiation aspiration is significantly negative $(\beta=-.20, p<.05)$. Integration exhibits a significantly more negative effect on negotiation aspiration for services ( $\beta=-.53, p<.01)$ than for goods $(\beta=-.15, p>.10)$, supporting H8. Finally, the effect of negotiation aspiration on negotiated price is significantly negative $(\beta=-.15, p<.05)$, confirming $\mathrm{H} 6$.

Robustness checks We conducted two supplemental analyses to verify the robustness of our results. First, we repeated our estimation without including control variables. Results appear in Model 2 of Table 4 and are largely in line with Model 1, supporting the results' robustness. Second, our model employs single-source data, which may give rise to common method variance (Podsakoff et al. 2003). Web Appendix W5.2 describes several precautions to rule out common method bias.

\section{Hypotheses (Part 3): Communication strategies}

Our previous hypotheses propose that if a service exhibits high heterogeneity and low integration, ${ }^{2}$ customers develop higher negotiation aspirations, which result in lower negotiated prices. From the perspective of service providers, the question arises as to how best to reduce customers' negotiation aspirations so as to secure price enforcement. We conceive four potential communication strategies to improve price enforcement when selling services with high heterogeneity and low integration. These strategies build on prior literature showing that customer perceptions in negotiations can easily be mended through specific communication strategies (Bhatia and Gunia 2018; Malhotra and Bazerman 2008).

Negotiation illegitimacy framing As we hypothesized earlier, owing to a service's heterogeneity, customers may infer negotiating to be particularly formatting and legitimate To counteract this inference, salespeople might clarify that a service is non-negotiable, shifting customers' perceptions toward the view that negotiating is illegitimate.

\footnotetext{
${ }^{2}$ In this section, we focus on integration rather than inseparability for methodological reasons. Specifically, to test the subsequent hypotheses, we aim to manipulate a service to exhibit "unfavorable" characteristics that increase customers' negotiation aspiration and assess the impact of communication strategies. However, the degree to which a service exhibits inseparability should be decisively driven by the specific service category, which renders it difficult to manipulate inseparability of a given service as high or low. Manipulating the degree to which a customer is integrated in the service delivery is more feasible. Importantly, as suggested in H5 and H8, customers' reasons for developing elevated negotiation aspirations for separable and non-integrated services should be similar, that is, a decrease in perceived negotiation risk.
}

Price transparency framing We have argued that because of their uncertainty regarding a service's price fairness, customers perceive negotiating over services as legitimate (Bolton and Alba 2006; Martín-Ruiz and Rondán-Cataluña 2008). To increase perceptions of price fairness and thus reduce negotiation legitimacy, salespeople may give customers an overview of market prices that clarifies that the requested price of a service is fair. With an understanding of fair prices, customers may be less likely to perceive negotiating as legitimate.

Product security framing Owing to a service's heterogeneity, customers may infer product risk and aspire to reduce their potential loss (Roth and Rothblum 1982). To counteract this inference, salespeople might provide reassurance that they will satisfy customers' needs, thereby evoking perceptions of security rather than risk.

Negotiation risk framing When customers are integrated in a service process, they may infer that negotiating may impair the customer-service provider relationship and result in reduced service quality because a good relationship with service providers is indispensable (Amanatullah et al. 2008). To foster this inference, salespeople can emphasize the importance of good relationships with customers in their specific context, potentially stimulating customers' motivation to preserve the relationship and thus reduce their negotiation aspirations. Thus:

H9: Negotiation illegitimacy framing reduces customers' negotiation aspiration for services with high heterogeneity and low integration.

H10: Price transparency framing reduces customers' negotiation aspiration for services with high heterogeneity and low integration.

H11: Product security framing reduces customers' negotiation aspiration for services with high heterogeneity and low integration.

H12: Negotiation risk framing reduces customers' negotiation aspiration for services with high heterogeneity and low integration.

\section{Study 5: Testing effective salesperson strategies for services negotiations}

\section{Motivation}

Our previous studies indicated that services negotiations constitute a double-edged sword. On the one hand, customers aspire to higher negotiation outcomes owing to the heterogeneity of services, which leads them to perceive negotiation legitimacy and 
product risk. On the other hand, customers have lower negotiation aspirations owing to the inseparability of servicesparticularly when they are integrated in the service process and thus concerned about ramifications of negotiating. For managerial practice, the question arises as to how employees may use these findings to reduce customers' aspirations in services negotiations, thus improving suppliers' price enforcement and profitability. In this respect, H9-H12 proposed a set of communication strategies, which Study 5 tests empirically.

\section{Procedure}

We acquired 307 participants from Mechanical Turk (56\% male; mean age, 34 years) and simulated the purchase of a tax consultation service. As Web Appendix 1.2 shows, over $30 \%$ of actual customers engage in price negotiations when purchasing such a service, providing sufficient variance for studying customers' negotiation behavior in this context.

We randomly assigned participants to six experimental conditions. The first two conditions serve as control conditions to evaluate the effectiveness of the communication strategies. Specifically, as argued in H9-H12, our communication strategies aim to reduce customers' negotiation aspirations in situations in which heterogeneity is high and integration is low. Therefore, in our first experimental control condition ("unfavorable IHIP") we specified heterogeneity as high and integration as low without including a communication strategy. We expect our communication strategies to significantly decrease negotiation aspiration compared to this first control condition. To further evaluate the effectiveness of our communication strategies, we added a second control condition ("favorable IHIP") with low heterogeneity and high integration, as our previous studies suggest this specification of heterogeneity and integration should lead to low negotiation aspirations. Thus, this control condition will allow us to evaluate the extent to which our communication strategies decrease negotiation aspirations.

To manipulate the tax consultant's heterogeneity, we provided participants with one- to four-star evaluations from 100 prior customers. In the low heterogeneity condition, all prior customers had given the tax consultant three stars whereas in the high heterogeneity condition star ratings varied, yet also resulted in an average three-star rating. To manipulate integration, we described the tax consultation process. In the low integration condition, the tax consultant worked largely independently from customers whereas in the high integration condition, participants would be strongly involved in the service delivery.

The third to sixth experimental conditions comprise unfavorable IHIP to evoke high negotiation aspiration as well as the tax consultant's application of communication strategies as laid out in H9- 112 - that is, negotiation illegitimacy framing, price transparency framing, product security framing, and negotiation risk framing. Web Appendix W6.1 provides the detailed manipulations. After reading the scenario, participants stated whether they would ask for a discount. Those who did entered their first price offer as in the previous studies. Given our previous studies' strong evidence of the effect of negotiation aspiration on negotiated price, we omitted the negotiation simulation in this study. Thus, in Study 5 negotiation aspiration is the ultimate outcome variable.

\section{Measures}

The operationalization of negotiation aspiration was the same as that in the previous studies. For participants who did not ask for a discount, negotiation aspiration was set to 0 . For those who made a counter-offer, negotiation aspiration was set to the discount claimed. As in Studies 1, 2, and 3, we collected customers' general negotiation propensity and negotiation expectation as control variables. The Appendix provides information on all survey scales, Web Appendix W6.2 provides statistics on all experimental cells, and Web Appendix W6.3 provides validity checks.

\section{Results}

To test H9-H12, we inspected the mean value of negotiation aspiration (Fig. 3). An initial single-factor ANOVA suggested significant mean differences across the treatment conditions $(\mathrm{F}(5,301)=2.42, p<.05)$.

Post hoc contrasts provided the following insights. First, as expected, negotiation aspiration was higher in the first control condition (unfavorable IHIP) than in the second control condition (favorable IHIP; $\mathrm{M}_{\text {unfavorable IHIP }}=128.31, \mathrm{M}_{\text {favorable IHIP }}=$ 87.22; $\mathrm{F}(1,301)=3.96, p<.05)$. This finding confirms our previous results that customers aspire to higher price discounts if heterogeneity is high and integration is low ( $\mathrm{H} 1$ and $\mathrm{H} 8)$.

Second, in H9 we suggested that framing a negotiation as illegitimate reduces negotiation aspiration for services with high heterogeneity and low integration. In line with this prediction, negotiation aspiration in the negotiation illegitimacy condition is significantly lower than in the unfavorable IHIP control condition $\left(\mathrm{M}_{\text {unfavorable IHIP }}=128.31, \mathrm{M}_{\text {negotiation illegit- }}\right.$ imacy framing $=57.96 ; \mathrm{F}(1,301)=11.24, p<.01)$ and not statistically different from the favorable IHIP control condition $\left(\mathrm{M}_{\text {favorable IHIP }}=87.22, \mathrm{M}_{\text {negotiation illegitimacy framing }}=\right.$ $57.96 ; \mathrm{F}(1,301)=1.93, p>.10)$. Thus, H9 is supported.

H10 proposes that creating price transparency reduces negotiation aspiration for services with high heterogeneity and low integration. Fully in line with this hypothesis, negotiation aspiration in the price transparency framing condition is significantly lower than in the unfavorable IHIP control condition $\left(\mathrm{M}_{\text {unfavorable IHIP }}=128.31, \mathrm{M}_{\text {price transparency framing }}=\right.$ $81.68 ; \mathrm{F}(1,301)=5.43, p<.05)$ and not statistically different from the favorable IHIP control condition $\left(\mathrm{M}_{\text {favorable IHIP }}=\right.$ 


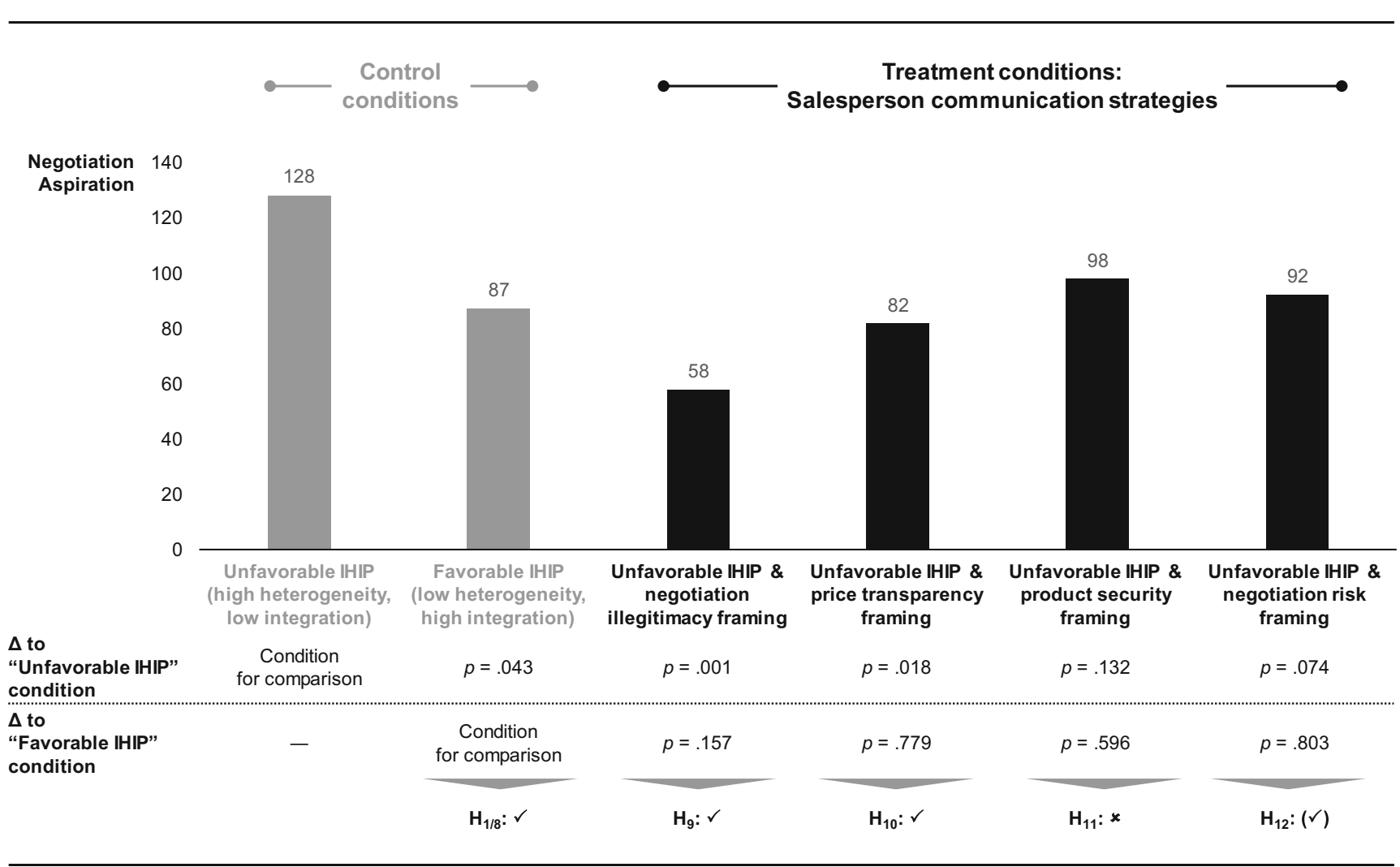

Fig. 3 Study 5: Results

87.22, $\mathrm{M}_{\text {price transparency framing }}=81.68 ; \mathrm{F}(1,301)=.08, p>$ .10). Thus, H10 is supported.

In $\mathrm{H} 11$ we proposed that product security framing reduces negotiation aspiration for services with high heterogeneity and low integration. Negotiation aspiration in the product security framing condition is lower than in the unfavorable IHIP control condition, but the difference is not significant $\left(\mathrm{M}_{\text {unfavorable }}\right.$ $\mathrm{IHIP}=128.31, \mathrm{M}_{\text {product security framing }}=97.94 ; \mathrm{F}(1,301)=2.18$, $p>.10)$. Thus, H11 is rejected although the effect is directionally consistent.

Eventually, in H12 we suggested that negotiation risk framing reduces negotiation aspiration for services with high heterogeneity and low integration. Corroborating this hypothesis, negotiation aspiration in the negotiation risk framing condition is lower than in unfavorable IHIP control condition at marginal significance $\left(\mathrm{M}_{\text {unfavorable IHIP }}=128.31, \mathrm{M}_{\text {negotiation }}\right.$ risk framing $=92.26 ; \mathrm{F}(1,301)=3.08, p<.10)$ and not statistically different from the favorable IHIP control condition $\left(\mathrm{M}_{\text {favorable IHIP }}=87.22, \mathrm{M}_{\text {negotiation risk framing }}=92.26 ; \mathrm{F}(1\right.$, $301)=.06, p>.10)$. Thus, $\mathrm{H} 12$ receives some support.

Robustness checks In line with Studies 1, 2, and 3, we repeated our analyses while controlling for general negotiation propensity and negotiation expectations. Results remained fully stable, providing support that they are not unduly influenced by omitted variable bias.

\section{Discussion}

\section{Research issues}

According to Herbst, Voeth, and Meister (2011, p. 976), "buyer-seller negotiations are an important, but still inadequately treated aspect within marketing research." One inadequately treated aspect is the question of how price negotiations for services and goods differ. Given the high theoretical and practical relevance of this question, we devised five studies to explore the effect of services versus goods on a customer's negotiation aspiration and analyzed psychological mechanisms and boundary conditions.

Our work contributes to academic knowledge in several ways. First, the study's unique contribution lies in the integration of two well established theoretical frameworks - the IHIP framework (Zeithaml et al. 1985) and aspiration level theory (Siegel and Fouraker 1960). Specifically, we develop a theoretical rationale and provide empirical evidence suggesting that customers form negotiation aspirations on the basis of an offering's heterogeneity and inseparability. We hereby fill the research void regarding whether and how services negotiations differ from goods negotiations. Negotiation aspirations rise because services tend to exhibit higher heterogeneity, leading customers to perceive negotiation legitimacy and product risk. Notably, this effect is consistently predicted by 
perceived risk theory (Bauer 1960; Cox 1967; Cunningham 1967), according to which individuals aim to reduce potential losses if they face uncertain outcomes (as with heterogeneous services). We fortify our theoretical argument by showing that negotiation aspirations increase more strongly for customized services, which we attribute to the fact that customization increases heterogeneity (Gwinner et al. 2005; Parasuraman et al. 1988).

However, this effect via heterogeneity is offset by lower negotiation aspirations owing to a service's inseparability. Both our theoretical analyses and our empirical evidence suggest that customers fear damaging their relationship with a service provider if they negotiate aggressively, potentially resulting in lower service quality. We buttress this argument by showing that negotiation aspirations increase less strongly, or decrease more strongly, for high customer integration in a service. We attribute this effect to integrated customers' motivation to preserve the relationship with a service provider (e.g., Lax and Sebenius 1986) and to maintain a positive self-image (e.g., Habel et al. 2017) (see H8).

Our finding that a service's inseparability of production and consumption leads customers to fear that negotiating lessens service quality connects well with both prior negotiation literature and prior services literature. Negotiation literature has long recognized the trade-off negotiators face between improving their outcomes and preserving a good relationship with their counterpart (e.g., Lax and Sebenius 1986). Negotiators who highly value the relationship negotiate less assertively (e.g., Amanatullah et al. 2008; Wieseke et al. 2014). In addition, services literature has emphasized that customers infer service quality from the price they have to pay (e.g., Grewal et al. 2000). Our study connects the two research streams by illustrating that when it comes to services, a customer's price-quality inference and concern for the relationship with a service provider may actually be two sides of the same coin. We consider this association to be the most intriguing implication from our combination of the IHIP framework and aspiration level theory.

The second contribution of this paper for academia lies in its methodological implications for future negotiation research. Our study illustrates that customers' negotiation behavior is affected by whether an offering is a good or a service, specifically by characteristics such as heterogeneity, inseparability, customization, and integration. Importantly, negotiation literature has often neglected to consider these effects and focused on either goods (e.g., White and Neale 1994), services (e.g., Adam and Shirako 2013), or a combination of the two without distinction (e.g., Van Kleef et al. 2004), or has not specified the type of the negotiated object (e.g., Moosmayer et al. 2012). As services negotiations may differ from goods negotiations, we recommend that to reduce omitted variable bias, future negotiation studies control for the offering type. Several studies have examined the effect of relationships between negotiators on negotiation behavior (e.g., Amanatullah et al. 2008; Wieseke et al. 2014; Alavi et al. 2016), and possibly the effects uncovered by this literature are particularly pronounced when negotiating about customized and integrated services, because in this context relationships are of heightened importance. Examining such boundary conditions of prior literature constitutes an interesting avenue for future research.

Third, our study conceptualizes and empirically verifies four novel communication strategies that successfully reduce customers' aspirations when negotiating about services with high heterogeneity and low integration - that is, services that tend to arouse negotiation aspirations - thereby contributing to literature on influence tactics in price negotiations (e.g., Malhotra and Bazerman 2008). Studies in this literature have shown that customers' negotiation behavior can easily be influenced through minor communicative changes, such as specifics of price anchors (e.g., Bhatia and Gunia 2018), the display of functional and relational customer orientation (e.g., Wieseke et al. 2014), or the priming of fairness (e.g., Maxwell et al. 1999). Our strategies are similar, as only small changes in salespeople's communication have significant effects on customers' negotiation aspirations. We encourage testing of these strategies in the field and across various negotiation contexts.

\section{Managerial implications}

Managers have long complained that salespeople grant discounts too easily (Joseph 2001; CSO Insights 2014). These concerns have been fueled by the increasing servitization of companies, which increases negotiations with customers (Sharma and Krishnan 2001). To help managers avoid excessive discounting of services, our study provides two sets of recommendations.

Reduction of aspirations First, managers can present their services in a way that reduces customers' negotiation aspirations. Two avenues seem particularly promising in this respect, relating to heterogeneity and inseparability. Particularly if their services are customized, managers may work toward reducing customers' perceived heterogeneity. As a result, customers should perceive negotiating as less legitimate and be less inclined to reduce their risk by negotiating down the price. To reduce perceived heterogeneity, managers may emphasize their service's quality and quality control on the level of resources, processes, and outcomes (Donabedian 1966). On a resource level, for example, managers can emphasize the selection and training of their personnel (e.g., Zeithaml et al. 1985), as McKinsey does by stressing that it hires employees who are "at the top of their fields" (McKinsey 2018). On a process level, managers might industrialize services by "substitut[ing] organized preplanned systems for individual 
service operations" (Zeithaml et al. 1985, p. 35). For example, management consulting firms frequently develop and publish standardized approaches for delivering customized advice to their customers (O'Mahoney and Sturdy 2016). Moreover, companies can emphasize how their use of automation technologies, including artificial intelligence, controls service quality and thus secures value for customers (Huang and Rust 2018; Singh et al. 2019). For example, financial service providers might detect credit card fraud through artificial intelligence and thus reduce customers' perceived risk (Yee et al. 2018). Last, on an outcome level, managers might illustrate their consistently high service quality through reference customers. For example, proposals of management consulting firms typically contain an overview of reference projects that illustrate how the firm has successfully solved similar challenges of other industry players. Managers can also stress their services' inseparability and the integration of customers in the service process, leading customers to be more careful not to harm the relationship through tough negotiations. For example, the mission statement of the Boston Consulting Group (BCG 2018) states, "We work with our clients to build the capabilities that enable organizations to achieve sustainable advantage. We are shaping the future. Together."

Training in communication strategies Second, managers should prepare their sales staff for customers' increasing negotiation aspirations when selling services with high heterogeneity and low inseparability or integration. To this end, managers can train their sales staff in the communication strategies our study devised and empirically verified. The most promising communication strategies for reducing customers' negotiation aspirations are to simply state that prices are nonnegotiable (e.g., "As is common in our industry, we follow a fixed price policy, so our prices are not negotiable") or to create price transparency that illustrates the fairness of the requested price (e.g., "As you can see on this list, the price for this product is a fair market price"). However, we acknowledge that sales staff may hesitate to use these strategies because they may perceive them as confrontational or overly focused on the issue of pricing instead of value (e.g., Hoffman 2018). Therefore, a viable alternative may be to stress the importance of a good relationship with customers (e.g., "It is important to me that we have very good relationship. After all, we will interact very closely during the service delivery").

\section{Limitations and avenues for future research}

Two limitations of our manuscript that provide avenues for future research are its focus on (1) sequential price negotiations and (2) its use of steady states rather than companies' servitization. As to the first, an interesting question is to what extent our findings are generalizable from sequential negotiations to other pricing contexts, such as price bidding (e.g., Haruvy and Popkowski Leszczyc 2016). On the basis of our findings, we would expect services versus goods to exhibit a pattern of effects on customers' bids similar to that on customers' negotiation aspirations. However, we would expect the heterogeneity path to outweigh the inseparability path because by initiating a bidding process a service provider specifies bidding as the "rule of the game," which a customer merely follows. Thus, compared to proactively initiating a price negotiation, customers should be less concerned about damaging the relationship through bidding. The second limitation that future research could explore is our neglect of increasing servitization over time. Our studies investigate steady states in which customers negotiate about either goods or services. An interesting question is whether and how the effects uncovered by our studies emerge when a firm "servitizes" its goods, as with Rolls Royce's pivot from selling jet engines to selling "power by the hour" (Singh et al. 2019). Specifically, would customers instantly perceive increased heterogeneity and inseparability with their countervailing effects on negotiation aspiration? By delving into this question, future research could provide guidance to firms switching from a goodscentric to a service-centric approach.

\section{Appendix}

Table 5 Survey measurements

IHIP Dimensions:

Intangibility (Zeithaml, Parasuraman, and Berry 1985) / Studies 1, 2

Definition: Extent to which an offering cannot be seen, felt, tasted, or touched

$\alpha$ / AVE / CR:Study 1: .93 / .83 / .94; Study 2: .90 /.75/.90

The offering that I negotiated about is ...

- tangible / intangible ${ }^{\mathrm{a}, 1,2}$

- material / immaterial ${ }^{\mathrm{a}, 1,2}$

- physical / not physical ${ }^{\mathrm{a}, 1,2}$

Heterogeneity (Zeithaml, Parasuraman, and Berry 1985) / Studies 1, 2

Definition: Extent to which the performance of a service is variable

$\alpha$ / AVE / CR: Study 1: .70 /.62 /.79; Study 2: .91/.78/.91

The performance of the offering that I negotiated about ...

- is the same for every customer / can vary from customer to customer ${ }^{\mathrm{a}, 1,2}$

- is identical for every customer / is different for every customer ${ }^{\mathrm{a}, 1,2}$

- strongly adapted to individual customers ${ }^{\mathrm{b}, 1}$

- is always the same / fluctuates ${ }^{\mathrm{a}, 2}$

Inseparability (Zeithaml, Parasuraman, and Berry 1985) / Studies 1, 2

Definition: Extent to which an offering is produced and consumed simultaneously

$\alpha$ / AVE / CR: Study 1: .91 /.74 /.90; Study 2: .76 / — / -

The offering that I negotiated about is ...

- first produced and then consumed / produced and consumed simultaneously $\mathrm{a}, 1,2$

- consumed only after it is produced / consumed while it is being produced $^{\mathrm{a}, 1}$

- produced before I'm using it / produced while I'm using it ${ }^{\mathrm{a}, 1}$

- produced and consumed at different times / produced and consumed at the same time ${ }^{\mathrm{a}, 2}$

Perishability (Zeithaml, Parasuraman, and Berry 1985) / Studies 1, 2

Definition:Extent to which an offering cannot be saved

$\alpha$ / AVE / CR:Study 1: .92 /.79 / .92; Study 2: .85 / .67 / .86 
Table 5 (continued)

The offering that I negotiated about is ...

- can be saved and used later / cannot be saved and used later ${ }^{\mathrm{a}, 1,2}$

- can be stored / cannot be stored $d^{\mathrm{a}, 1,2}$

- can be consumed any time / can only be consumed once $e^{\mathrm{a}, 1,2}$

Customers' inferences:

Negotiation Legitimacy (Oliver, Balakrishnan, and Barry 1994) / Study 2

Definition: Perception that bargaining for an offering is customary

$\alpha /$ AVE / CR: Study 2: .78 /.59 /.79

- If I negotiated in this situation, most people who are important to me would disapprove. (reverse coded) $)^{\mathrm{b}, 2}$

- For this type of offering, I usually get a discount. ${ }^{\mathrm{b}, 2}$

- For this type of offering, usually the price can be changed to my advantage. ${ }^{\mathrm{b}, 2}$

- For this type of offering, I usually receive a price concession. ${ }^{\mathrm{b}, 2}$ Product Risk (Hoover et al. 1978) / Study 2

Definition:Perception that purchasing an offering may have unpleasant results

$\alpha /$ AVE / CR:Study 2: $.85 /-/$ -

- In sum, I would fear a loss if I buy this offer. ${ }^{\mathrm{b}, 2}$

- I would be very uncertain whether the offer satisfies my needs. ${ }^{b, 2}$

Negotiation Risk (Hoover et al. 1978) / Study 2

Definition:Perception that bargaining may result in lower service quality

$\alpha$ / AVE / CR:Study 2: .89 /.75/.90

If I negotiated very tough in this situation, I would fear ...

-... that the performance of the offering would be reduced. ${ }^{\mathrm{b}, 2}$

-... that I would receive an inferior offering., ${ }^{\mathrm{b}, 2}$

-... that I would receive a lower-quality offering., ${ }^{\mathrm{b}}$,

Dependent Variable:

Negotiation Aspiration (Siegel and Fouraker 1960) / Studies 1, 2, 3, 5

Definition: Extent to which an offering cannot be seen, felt, tasted, or touched

Discount claimed in the first negotiation round, that is, list price minus first offer $^{1,2,3,5}$

Negotiation Aspiration (Alavi et al. 2018) / Study 4

$\alpha$ / AVE / CR:Study 4: .92 /.81/.93

In price negotiations about this offering, we are ...

- very hard ${ }^{\mathrm{b}, 4}$

- very tough ${ }^{\mathrm{b}, 4}$

- very persistent ${ }^{\mathrm{b}, 4}$

Moderators:

Customization (Müller et al. 2017) / Study 4

Definition: Extent to which an offering is individually tailored to a customer

$\alpha$ / AVE / CR:Study 4: . 94 / .83/.94

- This offering is highly individualized. ${ }^{\mathrm{b}, 4}$

- This offering is highly adapted to our needs. ${ }^{\mathrm{b}, 4}$

- This offering is individually developed for us. ${ }^{\text {b, } 4}$

Integration (Homburg et al. 2013) / Study 4

Definition:Extent to which a customer acts as a co-producer of a service

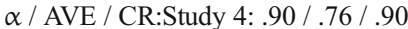

- Our business relationship with this firm is characterized by close cooperation between the two companies. ${ }^{\mathrm{b}, 4}$

- We have a close business relationship with this firm. ${ }^{\mathrm{b}, 4}$

- The business relationship with this firm can be better described as a

"cooperative effort" rather than an "arm's length negotiation.,",

Control variables:

We controlled for the following variables (refer to Web Appendix W7 for definitions, scales, and psychometric properties):

General Negotiation Propensity / Studies 1, 2, 3, 5; Negotiation Expectation / Studies 1, 2, 3, 5; Perceived Product Value / Studies 1, 2, 3, 5; Relationship Length / Study 4; Product Satisfaction / Study 4; Price Performance / Study 4; Competitive Intensity / Study 4; Company Revenue / Study 4; Company Employees / Study 4; Professional Experience / Study 4

a seven-point differential; ${ }^{\text {b }}$ seven-point Likert scale ("strongly disagree" to "strongly agree"); ${ }^{1}$ used in Study $1 ;{ }^{2}$ used in Study $2 ;{ }^{3}$ used in Study $3 ;{ }^{4}$ used in Study $4 ;{ }^{5}$ used in Study 5

Open Access This article is distributed under the terms of the Creative Commons Attribution 4.0 International License (http:// creativecommons.org/licenses/by/4.0/), which permits unrestricted use, distribution, and reproduction in any medium, provided you give appropriate credit to the original author(s) and the source, provide a link to the Creative Commons license, and indicate if changes were made.

\section{References}

Adam, H., \& Shirako, A. (2013). Not all anger is created equal: The impact of the expresser's culture on the social effects of anger in negotiations. Journal of Applied Psychology, 98(5), 785-798.

Aiken, L. S., \& West, S. G. (1991). Multiple regression: Testing and interpreting interactions. Thousand Oaks: Sage Publications.

Alavi, S., Habel, J., Guenzi, P., \& Wieseke, J. (2018). The role of leadership in salespeople's price negotiation behavior. Journal of the Academy of Marketing Science, 46(4), 703-724.

Alavi, S., Wieseke, J., \& Guba, J. H. (2016). Saving on discounts through accurate sensing-salespeople's estimations of customer price importance and their effects on negotiation success. Journal of Retailing, 92(1), 40-55.

Amanatullah, E. T., Morris, M. W., \& Curhan, J. R. (2008). Negotiators who give too much: unmitigated communion, relational anxieties, and economic costs in distributive and integrative bargaining. Journal of Personality and Social Psychology, 95(3), 723-738.

Bagga, C. K., Bendle, N., \& Cotte, J. (2018). Object valuation and nonownership possession: how renting and borrowing impact willingness-to-pay. Journal of the Academy of Marketing Science, 47(1), 121.

Bagozzi, R. P. (1977). Structural equation models in experimental research. Journal of Marketing Research, 14(2), 209-226.

Balakrishnan, P. V., \& Eliashberg, J. (1995). An analytical process model of two-party negotiations. Management Science, 41(2), 226-243.

Baron, R. M., \& Kenny, D. A. (1986). The Moderator-Mediator Variable Distinction in Social Psychological Research: Conceptual, Strategic, and Statistical Considerations. Journal of Personality and Social Psychology, 51(6), 1173-1182.

Barry, B., \& Friedman, R. A. (1998). Bargainer characteristics in distributive and integrative negotiation. Journal of Personality and Social Psychology, 74(2), 345-359.

Bauer, R. A. (1960). Consumer behavior as risk taking. In R. S. Hancock (Ed.), Dynamic Marketing for a Changing World (pp. 389-398). Chicago: American Marketing Association. Cited from Cox, D.F. (1967), Risk Taking and Information Handling in Consumer Behaviour (pp. 23-33). Boston: Harvard University Press.

BCG. (2018). Mission. https://www.bcg.com/about/mission/default.aspx. Accessed 26 Dec 2018

Bhatia, N., \& Gunia, B. C. (2018). "I was going to offer $\$ 10,000$ but...": The effects of phantom anchors in negotiation. Organizational Behavior and Human Decision Processes, 148(C), 70-86.

Bitner, M. J., Faranda, W. T., Hubbert, A. R., \& Zeithaml, V. A. (1997). Customer contributions and roles in service delivery. International Journal of Service Industry Management, 8(3), 193-205.

Bolton, L. E., \& Alba, J. W. (2006). Price fairness: Good and service differences and the role of vendor costs. Journal of Consumer Research, 33(2), 258-265.

Bowen, J. (1990). Development of a taxonomy of services to gain strategic marketing insights. Journal of the Academy of Marketing Science, 18(1), 43-49.

Carnevale, P. J., \& Isen, A. M. (1986). The influence of positive affect and visual access on the discovery of integrative solutions in bilateral negotiation. Organizational Behavior and Human Decision Processes, 37(1), 1-13.

Consumer Reports (2013). Learning how to bargain can reap big bucks. http://www.consumerreports.org/cro/magazine/2013/08/how-tobargain/index.htm. Accessed 30 April 2015 
Cox, D. F. (1967). Risk taking and information handling in consumer behaviour. Boston: Harvard University Press.

CSO Insights. (2014). Sales management optimization study: 2014 key trend analysis. Littleton: Miller Heiman Group.

Cunningham, S. M. (1967). The major dimensions of perceived risk. In D. F. Cox (Ed.), Risk Taking and Information Handling in Consumer Behaviour (pp. 82-111). Boston: Harvard University Press.

Darke, P. R., \& Dahl, D. W. (2003). Fairness and discounts: The subjective value of a bargain. Journal of Consumer Psychology, 13(3), $328-338$.

Donabedian, A. (1966). Evaluating the quality of medical care. The Milbank Memorial Fund Quarterly, 44(3), 166-206.

Edvardsson, B., Gustafsson, A., \& Roos, I. (2005). Service portraits in service research: a critical review. International Journal of Service Industry Management, 16(1), 107-121.

Edgett, S., \& Parkinson, S. (1993). Marketing for service industries - A review. The Service Industries Journal, 13(3), 19-39.

Gabbott, M., \& Hogg, G. (1994). Consumer behaviour and services: A review. Journal of Marketing Management, 10(4), 311-324.

Galinsky, A. D., \& Mussweiler, T. (2001). First offers as anchors: The role of perspective-taking and negotiator focus. Journal of Personality and Social Psychology, 81(4), 657-669.

Greenhalgh, L., \& Chapman, D. I. (1998). Negotiator relationships: Construct measurement, and demonstration of their impact on the process and outcomes of negotiation. Group Decision and Negotiation, 7(6), 465-489.

Greenhalgh, L., \& Gilkey, R. W. (1993). The effect of relationship orientation on negotiators' cognitions and tactics. Group Decision and Negotiation, 2(2), 167-183.

Grewal, D., Gotlieb, J., \& Marmorstein, H. (2000). The Moderating Effect of the Service Context on the Relationship Between Price and Post-Consumption Perceptions of Service Quality. Journal of Business and Psychology, 14(4), 579-591.

Grewal, D., Iyer, G. R., Gotlieb, J., \& Levy, M. (2007). Developing a deeper understanding of post-purchase perceived risk and behavioral intentions in a service setting. Journal of the Academy of Marketing Science, 35(2), 250-258.

Gwinner, K. P., Bitner, M. J., Brown, S. W., \& Kumar, A. (2005). Service customization through employee adaptiveness. Journal of Service Research, 8(2), 131-148.

Habel, J., Schons, L. M., Alavi, S., \& Wieseke, J. (2016). Warm glow or extra charge? The ambivalent effect of corporate social responsibility activities on customers' perceived price fairness. Journal of Marketing, 80(1), 84-105.

Habel, J., Alavi, S., \& Pick, D. (2017). When serving customers includes correcting them: Understanding the ambivalent effects of enforcing service rules. International Journal of Research in Marketing, 34(4), 919-941.

Haruvy, E., \& Popkowski Leszczyc, P. T. (2016). Measuring the impact of price guarantees on bidding in consumer online auctions. Journal of Retailing, 92(1), 96-108.

Hayes, A. F., \& Preacher, K. J. (2014). Statistical mediation analysis with a multicategorical independent variable. British Journal of Mathematical and Statistical Psychology, 67(3), 451-470.

Homburg, C., Stierl, M., \& Bornemann, T. (2013). Corporate social responsibility in business-to-business markets: How organizational customers account for supplier corporate social responsibility engagement. Journal of Marketing, 77(6), 54-72.

Hoover, R. J., Green, R. T., \& Saegert, J. (1978). A cross-national study of perceived risk. Journal of Marketing, 42(3), 102-108.

Huang, M. H., \& Rust, R. T. (2018). Artificial intelligence in service. Journal of Service Research, 21(2), 155-172.

Hüffmeier, J., Freund, P. A., Zerres, A., Backhaus, K., \& Hertel, G. (2014). Being tough or being nice? A meta-analysis on the impact of hard- and softline strategies in distributive negotiations. Journal of Management, 40(3), 866-892.

Huppertz, J. W., Arenson, S. J., \& Evans, R. H. (1978). An application of equity theory to buyer-seller exchange situations. Journal of Marketing Research, 15(2), 250-260.

Jang, H., \& Chu, W. (2012). Are consumers acting fairly toward companies? An examination of pay-what-you-want pricing. Journal of Macromarketing, 32(4), 348-360.

Jap, S., Robertson, D. C., \& Hamilton, R. (2011). The dark side of rapport: Agent misbehavior face-to-face and online. Management Science, 57(9), 1610-1622.

Joseph, K. (2001). On the optimality of delegating pricing authority to the sales force. Journal of Marketing, 65(1), 62-70.

Kopelman, S., Rosette, A. S., \& Thompson, L. (2006). The three faces of eve: Strategic displays of positive, negative, and neutral emotions in negotiations. Organizational Behavior and Human Decision Processes, 99(1), 81-101.

Lax, D. A., \& Sebenius, J. K. (1986). The manager as negotiator. New York: Free Press.

MacKenzie, S. B. (2001). Opportunities for improving consumer research through latent variable structural equation modeling. Journal of Consumer Research, 28(1), 159-166.

MacKinnon, D. P., Lockwood, C. M., \& Williams, J. (2004). Confidence limits for the indirect effect: Distribution of the product and resampling methods. Multivariate Behavioral Research, 39(1), 99-128.

MacMurray, B. K., \& Lawler, E. J. (1986). Level-of-aspiration theory and initial stance in bargaining. Representative Research in Social Psychology, 16(1), 35-44.

Malhotra, D., \& Bazerman, M. H. (2008). Psychological influence in negotiation: An introduction long overdue. Journal of Management, 34(3), 509-531.

Martín-Ruiz, D., \& Rondán-Cataluña, F. J. (2008). The nature and consequences of price unfairness in services: a comparison to tangible goods. International Journal of Service Industry Management, 19(3), 325-352.

Maxwell, S., Nye, P., \& Maxwell, N. (1999). Less pain, same gain: The effects of priming fairness in price negotiations. Psychology and Marketing, 16(7), 545-562.

McKinsey. (2018). Make your own McKinsey. https://www.mckinsey. com/careers/explore. Accessed 26 Dec 2018.

Mitchell, V. W., \& McGoldrick, P. J. (1996). Consumer's risk-reduction strategies: a review and synthesis. International Review of Retail, Distribution and Consumer Research, 6(1), 1-33.

Moosmayer, D. C., Schuppar, B., \& Siems, F. U. (2012). Reference prices as determinants of business-to-business price negotiation outcomes: An empirical perspective from the chemical industry. Journal of Supply Chain Management, 48(1), 92-106.

Müller, U., Habel, J., \& Stierl, M. (2017). Exerting Pressure or Leveraging Power? The Extended Chain of Corporate Social Responsibility Enforcement in Business-to-Business Supply Chains. Journal of Public Policy and Marketing, 36(2), 331-347.

Murray, K. B., \& Schlacter, J. L. (1990). The impact of services versus goods on consumers' assessment of perceived risk and variability. Journal of the Academy of Marketing Science, 18(1), 51-65.

Muthén, L. K., \& Muthén, B. O. (2012). Mplus user's guide: Statistical analysis with latent variables. Los Angeles: Muthén and Muthén.

O'Mahoney, J., \& Sturdy, A. (2016). Power and the diffusion of management ideas: The case of McKinsey \& Co. Management Learning, 47(3), 247-265.

Oliver, R. L., Balakrishnan, P. S., \& Barry, B. (1994). Outcome satisfaction in negotiation: A test of expectancy disconfirmation. Organizational Behavior and Human Decision Processes, 60(2), 252-275.

Parasuraman, A., Zeithaml, V. A., \& Berry, L. L. (1988). SERVQUAL: A multiple-item scale for measuring consumer perceptions of service quality. Journal of Retailing, 64(1), 12-40. 
Payne, A. F., Storbacka, K., \& Frow, P. (2008). Managing the co-creation of value. Journal of the Academy of Marketing Science, 36(1), 8396.

Podsakoff, P. M., MacKenzie, S. B., Lee, J. Y., \& Podsakoff, N. P. (2003). Common method biases in behavioral research: A critical review of the literature and recommended remedies. Journal of Applied Psychology, 88(5), 879-903.

Pruitt, D. G., \& Syna, H. (1985). Mismatching the opponent's offers in negotiation. Journal of Experimental Social Psychology, 21(2), 103-113.

Roth, A. E., \& Rothblum, U. G. (1982). Risk aversion and Nash's solution for bargaining games with risky outcomes. Econometrica, 50(3), 639-647.

Schneider, K. C., Rodgers, W. C., \& Bristow, D. N. (1999). Bargaining over the price of a product: Delightful anticipation or abject dread? Journal of Product and Brand Management, 8(3), 232-243.

Sharma, V. M., \& Krishnan, K. S. (2001). Recognizing the importance of consumer bargaining: Strategic marketing implications. Journal of Marketing Theory and Practice, 9(1), 24-37.

Shrout, P. E., \& Bolger, N. (2002). Mediation in experimental and nonexperimental studies: new procedures and recommendations. Psychological Methods, 7(4), 422-445.

Siegel, S., \& Fouraker, L. E. (1960). Bargaining and group decision making: Experiments in bilateral monopoly. New York: McGrawHill.

Sinaceur, M., Van Kleef, G. A., Neale, M. A., Adam, H., \& Haag, C. (2011). Hot or cold: Is communicating anger or threats more effective in negotiation? Journal of Applied Psychology, 96(5), 10181032.

Singh, J., Flaherty, K., Sohi, R. S., Deeter-Schmelz, D., Habel, J., Le Meunier-FitzHugh, K., Malshe, A., Mullins, R., \& Onyemah, V. (2019). Sales Profession and Professionals in the Age of Digitization and Artificial Technologies: Concepts, Priorities, and Questions. Journal of Personal Selling and Sales Management, $39(1), 2-22$.

Sundem, G. (2010). 10 Unexpected Things You Should Haggle Over. $\mathrm{http}: / /$ money.howstuffworks.com/personal-finance/budgeting/10 things-you-should-haggle-over.htm. Accessed 26 Dec 2018.

Thompson, L. (1995). The impact of minimum goals and aspirations on judgments of success in negotiations. Group Decision and Negotiation, 4(6), 513-524.

Thompson, L., \& Hastie, R. (1990). Social perception in negotiation. Organizational Behavior and Human Decision Processes, 47(1), 98-123.
Tukker, A. (2004). Eight types of product-service system: eight ways to sustainability? Experiences from SusProNet. Business Strategy and the Environment, 13(4), 246-260.

Van Kleef, G. A., De Dreu, C. K. W., \& Manstead, A. S. R. (2004). The interpersonal effects of emotions in negotiations: A motivated information processing approach. Journal of Personality and Social Psychology, 87(4), 510-528.

Vargo, S. L., \& Lusch, R. F. (2004). Evolving to a new dominant logic for marketing. Journal of Marketing, 68(1), 1-17.

Varman, R., \& Costa, J. A. (2008). Embedded markets, communities, and the invisible hand of social norms. Journal of Macromarketing, 28(2), 141-156.

Weber, E. U., \& Hsee, C. (1998). Cross-cultural differences in risk perception, but cross-cultural similarities in attitudes towards perceived risk. Management Science, 44(9), 1205-1217.

White, M. C. (2012). 12 Things You Should Always Haggle Over. http:// business.time.com/2012/08/13/12-things-you-should-alwayshaggle-over/slide/the-art-of-negotiating/. Accessed 26 Dec 2018.

White, S. B., \& Neale, M. A. (1994). The role of negotiator aspirations and settlement expectancies in bargaining outcomes. Organizational Behavior and Human Decision Processes, 57(2), 303-317.

Wieseke, J., Alavi, S., \& Habel, J. (2014). Willing to pay more, eager to pay less: The role of customer loyalty in price negotiations. Journal of Marketing, 78(6), 17-37.

Xia, L., Monroe, K. B., \& Cox, J. L. (2004). The price is unfair! A conceptual framework of price fairness perceptions. Journal of Marketing, 68(4), 1-15.

Yee, O. S., Sagadevan, S., \& Malim, N. H. A. H. (2018). Credit Card Fraud Detection Using Machine Learning As Data Mining Technique. Journal of Telecommunication, Electronic and Computer Engineering (JTEC), 10(1-4), 23-27.

Zeithaml, V. A., Bitner, M. J., \& Gremler, D. D. (2017). Services Marketing: Integrating customer focus across the firm (7th ed.). New York: McGraw-Hill.

Zeithaml, V. A., Parasuraman, A., \& Berry, L. L. (1985). Problems and strategies in services marketing. Journal of Marketing, 49(2), 3346.

Publisher's note Springer Nature remains neutral with regard to jurisdictional claims in published maps and institutional affiliations. 